Review

\title{
Endiandric Acid Derivatives and Other Constituents of Plants from the Genera Beilschmiedia and Endiandra (Lauraceae)
}

\section{Bruno Ndjakou Lenta ${ }^{1,2, *}$, Jean Rodolphe Chouna ${ }^{3}$, Pepin Alango Nkeng-Efouet ${ }^{3}$ and Norbert Sewald ${ }^{2}$}

1 Department of Chemistry, Higher Teacher Training College, University of Yaoundé 1, P.O. Box 47, Yaoundé, Cameroon

2 Organic and Bioorganic Chemistry, Chemistry Department, Bielefeld University, P.O. Box 100131, 33501 Bielefeld, Germany; E-Mail: norbert.sewald@uni-bielefeld.de

3 Department of Chemistry, University of Dschang, P.O. Box 67, Dschang, Cameroon; E-Mails:chounajr@yahoo.fr (J.R.C.); pnfalango@yahoo.fr (P.A.N.-E.)

* Author to whom correspondence should be addressed; E-Mail: lentabruno@yahoo.fr; Tel.: +2376-7509-7561.

Academic Editor: Jürg Bähler

Received: 3 March 2015 / Accepted: 6 May 2015 / Published: 14 May 2015

\begin{abstract}
Plants of the Lauraceae family are widely used in traditional medicine and are sources of various classes of secondary metabolites. Two genera of this family, Beilschmiedia and Endiandra, have been the subject of numerous investigations over the past decades because of their application in traditional medicine. They are the only source of bioactive endiandric acid derivatives. Noteworthy is that their biosynthesis contains two consecutive non-enzymatic electrocyclic reactions. Several interesting biological activities for this specific class of secondary metabolites and other constituents of the two genera have been reported, including antimicrobial, enzymes inhibitory and cytotoxic properties. This review compiles information on the structures of the compounds described between January 1960 and March 2015, their biological activities and information on endiandric acid biosynthesis, with 104 references being cited.
\end{abstract}

Keywords: Lauraceae; Beilschmiedia; Endiandra; chemical constituents; endiandric acid; alkaloids; biological activities 


\section{Introduction}

The family Lauraceae is one of the most important groups of Angiosperms and consists of 55 genera and over 2000 species [1-5]. Beilschmiedia is one of the largest pantropical genera in the Lauraceae, comprising about 250 species [6-8]. Most of its species grow in tropical climates, but few of them are native to temperate regions, and they are widespread in tropical Asia, Africa, Madagascar, Australia, New Zealand, North America, Central America, the Caribbean, and South America [6-8]. Regarding Endiandra, there are about 125 species found throughout the tropical regions, including 10 species in Malaysia [3,9-11]. Very little information is available on the medicinal use of plants of the Endiandra genus, but some Beilschmiedia species have been used in the indigenous system of medicine for the treatment of various disorders such as uterine tumours, rubella, female genital infections, rheumatism, colon and digestive disorders, malaria, headache, as well as bacterial or fungal infections [12-14]. The fruit of some species are used as appetite stimulants and also as spices [15-18].

Beilschmiedia and Endiandra species have been known for a long time as rich sources of biologically active secondary metabolites. They have been the subject of very intensive chemical investigations by various research groups starting from the middle of the 1960s, with a large number of compounds isolated from different species. However, phytochemical investigations have been mostly conducted on 31 species of Beilschmiedia (Beilschmiedia alloiophylla, B. anacardioides, B. bernesii, B. brevipes, B. chancho chancho, B. collina, B. costaricensis, B. cryptocaryoides, B. elliptica, B. erythrophloia, B. fulva, B. tsangii, B. ferruginea, B. kunstleri, B. madang, B. manii, B. miersii, B. obscura, B. obtusifolia, B. oligandra, B. oreophila Schlechter, B. pendula, B. podagrica, Beilschmiedia spp (from Gabon), B. talaranensis, B. tarairie, B. tawa, B. tooram, B. tovarensis, B. volckii, and B. zenkeri) [12,13,15-31] and 11 species of Endiandra (Endiandra anthropophagorum, E. bassaphila, E. baillonii, E. introsa, E. jonesii, E. kingiana, E. leptodendron, E. monothyra, E. palmerstonii, E. xanthocarpa, and E. wolfii) [32-43]. These investigations led to the isolation and characterization of various classes of secondary metabolites, of which endiandric acid derivatives, epoxyfuranoid lignans, kingianins (compounds with unique pentacyclic skeleton), and alkaloids exhibited antibacterial, anti-inflammatory, and anticancer activities and inhibited different enzymes [17-54]. Endiandric acid derivatives, polycyclic fatty acids that possess among others also anti-asthmatic activity have been isolated only from plants of the genera Beilschmiedia and Endiandra. The biosynthesis of this class of secondary metabolites contains two consecutive non-enzymatic electrocyclic reactions $[35,36,55]$.

\section{Chemical Constituents}

\subsection{Endiandric Acid Derivatives from Beilschmiedia and Endiandra}

Plants of the genera Beilschmiedia and Endiandra have been known for a long time as rich source of endiandric acid derivatives. They are still the only sources of this class of secondary metabolites. Endiandric acid derivatives have been found in 11 species of Beilschmiedia (Beilschmiedia anacardioides, B. alloiophylla, B. cryptocaryoides, B. erythrophloia, B. ferruginea, B. fulva, B. manii, Gaboneses Beilschmiedia spp, B. oligandra, B. obtusifolia, B. tooram, and B. tsangii) [17,19,20,22-24,44,48,52-54] and in 4 species of Endiandra (Endiandra baillonii, E. introsa, E. jonesii, and E. kingiana) [34,40]. All these compounds have some structural properties in common, such as the cyclic nature, the presence 
of double bonds and terminal carboxylic acid groups. They can be grouped according to the carbon skeleton layout into three groups. The first group is that of compounds characterized by a 13 carbon atom fused tetracyclic ring system containing $\Delta^{8,9}$ and $\Delta^{4,5}$ or $\Delta^{5,6}(\mathbf{1})$; the second group is that of compounds with tetracylic ring system formed with 11 carbon atoms with $\Delta^{10,11}(\mathbf{2})$ and the last group contains compounds that possess $b i$-, tri- or tetracyclic ring systems other than skeleton $\mathbf{1}$ and 2. The side chain attached to C-11 in $\mathbf{1}$ or C-4 in $\mathbf{2}$ contains in some case double bonds, phenyl residues, or a methylenedioxyphenyl moiety. The substituents at C-6 in $\mathbf{1}$ or C-8 in $\mathbf{2}$ are usually a carboxylic acid, a phenyl ring or a methylenedioxyphenyl fragment.
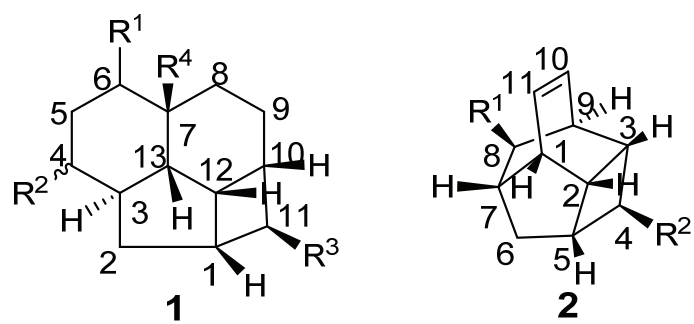

2.1.1. Endiandric Acid Derivatives with an 13 Carbon Atoms Fused Tetracyclic Ring System (Table 1)

The first members of this class of compound, endiandric acid A and B (3-4) were isolated from the leaves of Endiandra introrsa [35-39]. Endiandric acid A (3) was also obtained from the leaves of other species such as B. obtusifolia and B. oligandra [40]. Endiandric acid B (4) was also isolated from E. jonesii, E. baillonii and B. tooram [40]. In addition to endiandric acid A (1), a new derivative, 3",4"-methylenedioxy endiandric acid A (5) was obtained from B. oligandra after methylation of the extract and isolation of the non-natural methylated derivative 6 [40]. Endiandric acid H (7), a derivative with a hydroxyl group at C-4, was isolated from the stem of Beilschmiedia fulva [53,54]. Other endiandric acid analogues of this group with $\mathrm{C}_{8}$ alkyl side chain attached to the carbon $\mathrm{C}-11$, named beilschmiedic acid A-E (8-12), in addition with beilschmiedic acid F (13) were isolated from the stem bark of B. anacardioides $[17,19,20]$.

From the leaves of an unidentified Beilschmiedia species from Gabon, eight new beilschmiedic acid derivatives, named beilschmiedic acid H-O (14-21) were isolated using high-throughput natural products chemistry methods [48]. These compounds possess a phenylalkyl side chain at C-11, containing generally two trans-configured double bonds. A cis double bond, not reported previously in the side chain of endiandric acid derivatives was observed in beilschmiedic acid M (18) [48]. Beilschmiedic acid $\mathrm{N}$ (20) contains an unusual endoperoxide phenyl moiety that might have been formed during the process of isolation [48].

The phytochemical investigation of the root of B. erythrophloia resulted in the isolation of endiandric acid derivatives erythrophloins A-F (22-27) [41].

Endiandric acids with 13 carbon atoms fused tetracyclic ring system tsangibeilin A (28), tsangibeilin B (29), tsangibeilin C (30), tsangibeilin D (31) and the amide endiandramide A (32) have also been isolated from the roots of $B$. tsangii $[22,23,52]$.

Four beilschmiedic acid derivatives with different oxidation states at C-4, cryptobeilic acids A-D (33-36), together with the known tsangibeilin B (29) were isolated from the bark of B. cryptocaryoides collected in Madagascar [52]. Other endiandric acid analogues, named ferrugineic acids A-J (37-46) were isolated 
from the leaves and flowers extracts of $B$. ferruginea with the help of ${ }^{1} \mathrm{H}$ and ${ }^{13} \mathrm{C}$ HSQC NMR screening of ethyl acetate extracts and fractions [24].

The investigation of the methanolic extract of the bark of Endiandra kingiana led to the isolation of further endiandric acid analogs kingianic acids F (47), G (48) and endiandric acid (49) [34].

Table 1. Substitution pattern of endiandric acid derivatives with skeleton $\mathbf{1}$.

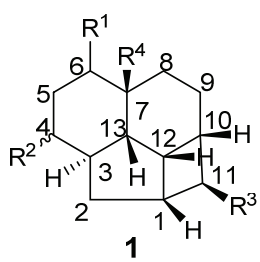

\begin{tabular}{|c|c|c|c|c|c|c|c|}
\hline Compounds & $\mathbf{R}^{1}$ & $\mathbf{R}^{2}$ & $\mathbf{R}^{3}$ & $\mathbf{R}^{4}$ & Unsaturation & Sources & Ref. \\
\hline Endiandric acid A (3) & Phenyl & $\mathrm{H}$ & $\mathrm{CH}_{2} \mathrm{COOH}$ & $\mathrm{H}$ & $\Delta^{4,5}, \Delta^{8,9}$ & $\begin{array}{l}\text { Leaves, B. obstusifolia, } \\
\text { B. tooram, E. introrsa }\end{array}$ & {$[35-40]$} \\
\hline Endiandric acid B (4) & Phenyl & $\mathrm{H}$ & $\mathrm{CH}_{2} \mathrm{CH}=\mathrm{CHCOOH}$ & $\mathrm{H}$ & $\Delta^{4,5}, \Delta^{8,9}$ & $\begin{array}{c}\text { Leaves, B. jonesii, } \\
\text { E. introrsa, B. tooram }\end{array}$ & [40] \\
\hline $\begin{array}{l}\text { 3",4"-methylenedioxy } \\
\text { Endiandric acid A (5) }\end{array}$ & & $\mathrm{H}$ & $\mathrm{CH}_{2} \mathrm{COOH}$ & $\mathrm{H}$ & $\Delta^{4,5}, \Delta^{8,9}$ & $\begin{array}{l}\text { Leaves, B. oligandra, } \\
\text { stem bark, B. manii, }\end{array}$ & {$[40,44]$} \\
\hline $\begin{array}{c}\text { 3",4"-methylenedioxy } \\
\text { Endiandric acid } \\
\text { A methyl ester (6) }\end{array}$ & & $\mathrm{H}$ & $\mathrm{CH}_{2} \mathrm{COOMe}$ & $\mathrm{H}$ & $\Delta^{4,5}, \Delta^{8,9}$ & $\begin{array}{l}\text { Synthesis, methylation } \\
\text { of } B \text {. oligandra extract }\end{array}$ & {$[40]$} \\
\hline Endiandric acid H (7) & & $\alpha-\mathrm{OH}$ & $\mathrm{CH}_{2} \mathrm{COOH}$ & $\mathrm{H}$ & $\Delta^{5,6}, \Delta^{8,9}$ & Stem, B. fulva & {$[53,54]$} \\
\hline Beilschmiedic acid A (8) & $\mathrm{COOH}$ & $\beta-\mathrm{OH}$ & & $\mathrm{H}$ & $\Delta^{5,6}, \Delta^{8,9}$ & Leave, Beilschmiedia spp & {$[17,48]$} \\
\hline Beilschmiedic acid B (9) & $\mathrm{COOH}$ & $\beta-\mathrm{OH}$ & & $\mathrm{OH}$ & $\Delta^{5,6}, \Delta^{8,9}$ & $\begin{array}{c}\text { Leaves, Beilschmiedia } \\
\text { spp; Bark, } \\
\text { B. anacardioides }\end{array}$ & {$[17]$} \\
\hline Beilschmiedic acid C (10) & $\mathrm{COOH}$ & $\alpha-\mathrm{OH}$ & & $\mathrm{H}$ & $\Delta^{5,6}, \Delta^{8,9}$ & $\begin{array}{c}\text { Leaves, Beilschmiedia } \\
\text { spp; Bark, } B . \\
\text { anacardioides }\end{array}$ & {$[17,48]$} \\
\hline Beilschmiedic acid D (11) & $\mathrm{COOH}$ & $\mathrm{H}$ & & $\mathrm{H}$ & $\Delta^{5,6}, \Delta^{8,9}$ & Bark, B. anacardioides & {$[20]$} \\
\hline Beilschmiedic acid E (12) & $\mathrm{COOH}$ & $\mathrm{H}$ & & $\mathrm{H}$ & $\Delta^{4,5}, \Delta^{8,9}$ & Bark, B. anacardioides & {$[20]$} \\
\hline Beilschmiedic acid F (13) & & $=\mathrm{O}$ & $\mathrm{CH}_{2} \mathrm{COOH}$ & $\mathrm{H}$ & $\Delta^{5,6}, \Delta^{8,9}$ & Bark, B. anacardioides & {$[19]$} \\
\hline Beilschmiedic acid H (14) & $\mathrm{COOH}$ & $\alpha-\mathrm{OH}$ & & $\mathrm{H}$ & $\Delta^{5,6}, \Delta^{8,9}$ & Leave, Beilschmiedia spp & [48] \\
\hline Beilschmiedic acid I (15) & $\mathrm{COOH}$ & $\beta-\mathrm{OH}$ & & $\mathrm{H}$ & $\Delta^{5,6}, \Delta^{8,9}$ & Leaves, Beilschmiedia spp & {$[48]$} \\
\hline Beilschmiedic acid J (16) & $\mathrm{COOH}$ & $\mathrm{H}$ & & $\mathrm{H}$ & $\Delta^{5,6}, \Delta^{8,9}$ & Leaves, Beilschmiedia spp & {$[48]$} \\
\hline Beilschmiedic acid K (17) & $\mathrm{COOH}$ & $\alpha-\mathrm{OH}$ & & $\mathrm{H}$ & $\Delta^{5,6}, \Delta^{8,9}$ & Leaves, Beilschmiedia spp & [48] \\
\hline Beilschmiedic acid M (18) & $\mathrm{COOH}$ & $\alpha-\mathrm{OH}$ & & $\mathrm{H}$ & $\Delta^{5,6}, \Delta^{8,9}$ & Leaves, Beilschmiedia spp & {$[48]$} \\
\hline Beilschmiedic acid L (19) & $\mathrm{COOH}$ & $\alpha-\mathrm{OH}$ & & $\mathrm{H}$ & $\Delta^{5,6}, \Delta^{8,9}$ & Leaves, Beilschmiedia spp & [48] \\
\hline
\end{tabular}


Table 1. Cont.

\begin{tabular}{|c|c|c|c|c|c|c|c|}
\hline Compounds & $\mathbf{R}^{1}$ & $\mathbf{R}^{2}$ & $\mathbf{R}^{3}$ & $\mathbf{R}^{4}$ & Unsaturation & Sources & Ref. \\
\hline Beilschmiedic acid N (20) & $\mathrm{COOH}$ & $\alpha-\mathrm{OH}$ & & $\mathrm{H}$ & $\Delta^{5,6}, \Delta^{8,9}$ & Leaves, Beilschmiedia spp & [48] \\
\hline Beilschmiedic acid O (21) & $\mathrm{COOH}$ & $\alpha-\mathrm{OH}$ & & $\mathrm{H}$ & $\Delta^{5,6}, \Delta^{8,9}$ & Leaves, Beilschmiedia spp & [48] \\
\hline Erythrophloin A (22) & COOMe & $\mathrm{H}$ & & $\mathrm{H}$ & $\Delta^{4,5}, \Delta^{8,9}$ & Roots, B. erythrophloia & [41] \\
\hline Erythrophloin B (23) & COOMe & $\mathrm{H}$ & & $\mathrm{H}$ & $\Delta^{4,5}, \Delta^{8,9}$ & Roots, B. erythrophloia & [41] \\
\hline Erythrophloin C (24) & COOMe & $\mathrm{H}$ & & $\mathrm{H}$ & $\Delta^{4,5}, \Delta^{8,9}$ & Roots, B. erythrophloia & [41] \\
\hline Erythrophloin D (25) & COOMe & $\mathrm{H}$ & & $\mathrm{H}$ & $\Delta^{4,5}, \Delta^{8,9}$ & Roots, B. erythrophloia & [41] \\
\hline Erythrophloin E (26) & $\mathrm{COOH}$ & $\mathrm{H}$ & & $\mathrm{H}$ & $\Delta^{4,5}, \Delta^{8,9}$ & Roots, B. erythrophloia & [41] \\
\hline Erythrophloin F (27) & $\mathrm{COOH}$ & $\mathrm{H}$ & & $\mathrm{H}$ & $\Delta^{4,5}, \Delta^{8,9}$ & Roots, B. erythrophloia & [41] \\
\hline Tsangibeilin A (28) & $\mathrm{COOH}$ & $\mathrm{H}$ & & $\mathrm{H}$ & $\Delta^{4,5}, \Delta^{8,9}$ & Roots, $B$. tsangii & [23] \\
\hline Tsangibeilin B (29) & $\mathrm{COOH}$ & $\mathrm{H}$ & & $\mathrm{H}$ & $\Delta^{4,5}, \Delta^{8,9}$ & $\begin{array}{c}\text { Roots, B. tsangii; } \\
\text { Bark, B. cryptocaryoides }\end{array}$ & {$[34,41,52]$} \\
\hline Tsangibeilin C (30) & $\mathrm{COOH}$ & $=\mathrm{O}$ & & $\mathrm{H}$ & $\Delta^{5,6}, \Delta^{8,9}$ & Roots, B. tsangii & {$[22]$} \\
\hline Tsangibeilin D (31) & $\mathrm{COOH}$ & $=\mathrm{O}$ & & $\mathrm{OH}$ & $\Delta^{5,6}, \Delta^{8,9}$ & Roots, $B$. tsangii & [22] \\
\hline Endiandramide A (32) & $\mathrm{CONHCH}_{2}$-ipr & $\mathrm{H}$ & & $\mathrm{H}$ & $\Delta^{45}, \Delta^{8,9}$ & Roots, B. tsangii & [23] \\
\hline Cryptobeilic acid A (33) & $\mathrm{COOH}$ & $\beta-\mathrm{OH}$ & & $\mathrm{H}$ & $\Delta^{5,6}, \Delta^{8,9}$ & Bark, B. cryptocaryoides & [52] \\
\hline Cryptobeilic acid B (34) & $\mathrm{COOH}$ & $\alpha-\mathrm{OH}$ & & $\mathrm{H}$ & $\Delta^{5,6}, \Delta^{8,9}$ & Bark, B. cryptocaryoides & [52] \\
\hline Cryptobeilic acid C (35) & $\mathrm{COOH}$ & $=\mathrm{O}$ & & $\mathrm{H}$ & $\Delta^{5,6}, \Delta^{8,9}$ & Bark, B. cryptocaryoides & [52] \\
\hline Cryptobeilic acid D (36) & $\mathrm{COOH}$ & $\mathrm{H}$ & & $\mathrm{H}$ & $\Delta^{4,5}, \Delta^{8,9}$ & Bark, B. cryptocaryoides & [52] \\
\hline Ferrugineic acid A (37) & $\mathrm{COOH}$ & $\mathrm{H}$ & & $\mathrm{H}$ & $\Delta^{4,5}, \Delta^{8,9}$ & $\begin{array}{c}\text { Leaves, flowers; } \\
\text { B. ferruginea }\end{array}$ & [24] \\
\hline Ferrugineic acid B (38) & $\mathrm{COOH}$ & $\mathrm{H}$ & & $\mathrm{H}$ & $\Delta^{4,5}, \Delta^{8,9}$ & $\begin{array}{c}\text { Leaves, flowers, } \\
\text { B. ferruginea }\end{array}$ & [24] \\
\hline Ferrugineic acid C (39) & $\mathrm{COOH}$ & $\mathrm{H}$ & & $\mathrm{H}$ & $\Delta^{4,5}, \Delta^{8,9}$ & $\begin{array}{c}\text { Leaves, flowers, } \\
\text { B. ferruginea }\end{array}$ & [24] \\
\hline Ferrugineic acid D (40) & $\mathrm{COOH}$ & $\mathrm{H}$ & & $\mathrm{H}$ & $\Delta^{4,5}, \Delta^{8,9}$ & $\begin{array}{c}\text { Leaves, flowers, } \\
\text { B. ferruginea }\end{array}$ & [24] \\
\hline Ferrugineic acid E (41) & $\mathrm{COOH}$ & $\mathrm{H}$ & & $\mathrm{H}$ & $\Delta^{4,5}, \Delta^{8,9}$ & $\begin{array}{c}\text { Leaves, flowers, } \\
\text { B. ferruginea }\end{array}$ & [24] \\
\hline Ferrugineic acid $\mathrm{F}$ (42) & $\mathrm{COOH}$ & $\alpha-\mathrm{OH}$ & & $\mathrm{H}$ & $\Delta^{5,6}, \Delta^{8,9}$ & $\begin{array}{c}\text { Leaves, flowers, } \\
\text { B. ferruginea }\end{array}$ & [24] \\
\hline Ferrugineic acid G (43) & $\mathrm{COOH}$ & $\beta-\mathrm{OH}$ & & $\mathrm{H}$ & $\Delta^{5,6}, \Delta^{8,9}$ & B. ferruginea & [24] \\
\hline Ferrugineic acid H (44) & $\mathrm{COOH}$ & $=\mathrm{O}$ & & $\mathrm{H}$ & $\Delta^{5,6}, \Delta^{8,9}$ & $\begin{array}{c}\text { Leaves, flowers, } \\
\text { B. ferruginea }\end{array}$ & [24] \\
\hline Ferrugineic acid I (45) & $\mathrm{COOH}$ & $\alpha-\mathrm{OH}$ & & $\mathrm{H}$ & $\Delta^{5,6}, \Delta^{8,9}$ & B. ferruginea & [24] \\
\hline
\end{tabular}


Table 1. Cont.

\begin{tabular}{|c|c|c|c|c|c|c|c|}
\hline Compounds & $\mathbf{R}^{1}$ & $\mathbf{R}^{2}$ & $\mathbf{R}^{3}$ & $\mathbf{R}^{4}$ & Unsaturation & Sources & Ref. \\
\hline Ferrugineic acid $\mathrm{J}(\mathbf{4 6})$ & $\mathrm{COOH}$ & $\beta-\mathrm{OH}$ & & $\mathrm{H}$ & $\Delta^{5,6}, \Delta^{8,9}$ & $\begin{array}{c}\text { Leaves, flowers, } \\
\text { B. ferruginea }\end{array}$ & [24] \\
\hline Kingianic acid F (47) & $\mathrm{COOH}$ & $\mathrm{H}$ & & $\mathrm{H}$ & $\Delta^{4,5}, \Delta^{8,9}$ & Bark, E. kingiana & [34] \\
\hline Kingianic acid G (48) & $\mathrm{COOH}$ & $\alpha-\mathrm{OH}$ & & $\mathrm{H}$ & $\Delta^{5,6}, \Delta^{8,9}$ & Bark, E. kingiana & [34] \\
\hline Endiandric acid (49) & $\mathrm{COOH}$ & $\mathrm{H}$ & & $\mathrm{H}$ & $\Delta^{5,6}, \Delta^{8,9}$ & Bark, E. kingiana & [34] \\
\hline
\end{tabular}

2.1.2. Endiandric Acid Derivatives with an 11 Carbon Atoms Fused Tetracylic Ring System (Table 2)

The first compound with this basic skeleton 2, endiandric acid C (50), was isolated from the leaves of Endiandra introrsa [38-40]. This compound was also obtained from the leaves of other species such as B. tooram, E. jonesii and E. baillonii [40]. From the root of B. erythrophloia, endiandric acid I (51) and endiandric acid J (52) were isolated [49]. Further investigation of this species afforded a methylketone derivative named beicyclone A (53) [41]. The investigation of the roots of B. tsangii, afforded the new derivatives endiandric acids K (54), L (55), M (56), and endrindramide B (57) having an amide group at C-8 [23].

From the leaves of $B$. ferruginea, one endiandric acid analogue, ferrugineic acid K (58) also with skeleton 2, was isolated. Other derivatives, kingianic acids A-E (59-63) with phenylalkyl side chains were isolated recently from the stem bark of E. kingiana [34].

Table 2. Structures of endiandric acid derivatives with skeleton 2.

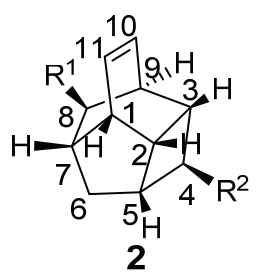

\begin{tabular}{|c|c|c|c|c|}
\hline Compounds & $\mathbf{R}^{1}$ & $\mathbf{R}^{2}$ & Sources & Ref. \\
\hline Endiandric acid C (50) & $\mathrm{COOH}$ & & B. tooram, B. oligandra, E. jonessi, E. introsa & {$[38,40]$} \\
\hline Endiandric acid I (51) & $\mathrm{COOH}$ & & Root, B. erythrophloia & [49] \\
\hline Endiandric acid J (52) & $\mathrm{COOH}$ & & Root, B. erythrophloia & [49] \\
\hline Beicyclone A (53) & $\mathrm{COCH}_{3}$ & & Root, B. erythrophloia & [41] \\
\hline Endiandric acid K (54) & $\mathrm{COOH}$ & & Roots, B. tsangii & {$[23]$} \\
\hline Endiandric acid L (55) & $\mathrm{CH}=\mathrm{CHCOOH}$ & & Roots of B. tsangii & [23] \\
\hline Endiandric acid M (56) & $\mathrm{CH}=\mathrm{CH}-\mathrm{COOH}$ & & Roots of B. tsangii, stem bark E. kingiana & {$[23,34]$} \\
\hline Endiandramide B (57) & $\mathrm{CONHCH}_{2} i \mathrm{Pr}$ & & B. tsangii & [23] \\
\hline Ferrugineic acid K (58) & $\mathrm{CH}=\mathrm{CH}-\mathrm{COOH}$ & & B. ferruginea & [24] \\
\hline Kingianic acid A (59) & $\mathrm{COOH}$ & & Stem bark, E. kingiana & [34] \\
\hline
\end{tabular}


Table 2. Cont.

\begin{tabular}{ccccc}
\hline Compounds & $\mathbf{R}^{1}$ & Sources & Ref. \\
\hline Kingianic acid B (60) & $\mathrm{COOH}$ & Stem bark, E. kingiana & {$[34]$} \\
Kingianic acid C (61) & $\mathrm{COOH}$ & Stem bark, E. kingiana & {$[34]$} \\
Kingianic acid D (62) & $\mathrm{COOH}$ & Stem bark, E. kingiana & {$[34]$} \\
Kingianic acid E (63) & Stem bark, E. kingiana & {$[34]$} \\
\hline
\end{tabular}

\subsubsection{Other Endiandric Acid Derivatives}

This group contains compounds that possess bi-, tri- or tetracyclic fused ring systems other than skeleton 1 and 2. In this group are beilschmiedic acid G (64) having an aromatic ring and beilschmiedin (65) with a seven-membered cyclic ether group isolated from B. anarcardiodes [19,20]; tricyclotsangibeilin, an endiandric acid derivative with cyclododecane ring system (66) isolated from the roots of B. tsangii [22] and the bicyclic endiandric acids D (67), E (68), F (69) and G (70) isolated from E. introrsa [35-40].

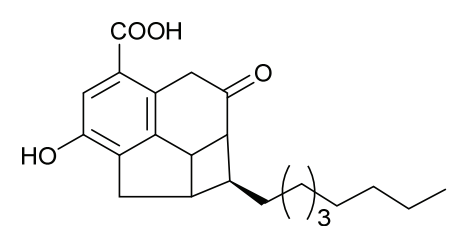

64

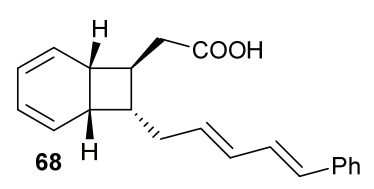

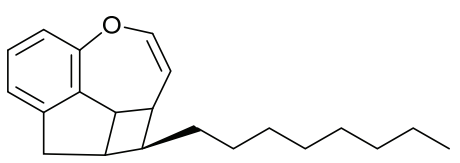

65

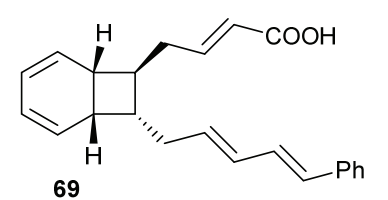

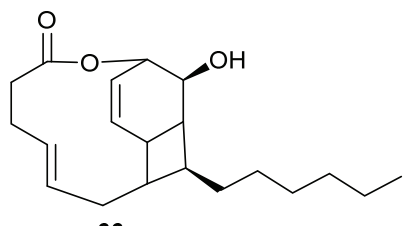

66

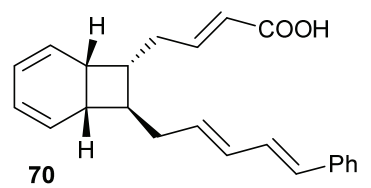

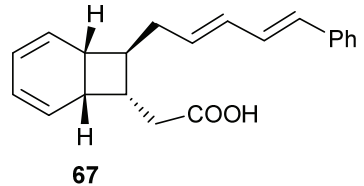

67

A total of 69 endiandric acid derivatives were isolated from 11 Beilschmiedia and four Endiandra plant species with the majority of these secondary metabolites having skeleton $\mathbf{1}$.

\subsubsection{Biosynthesis of Endiandric Derivatives}

Endiandric acids are polycyclic fatty acid derivatives with particular scaffolds isolated until date only in Beilschmiedia and Endiandra species of the Lauraceae family. They are products of electrocyclic ring closures of naturally occurring polyketides, resulting from both the shikimate and acetate pathways (Scheme 1).
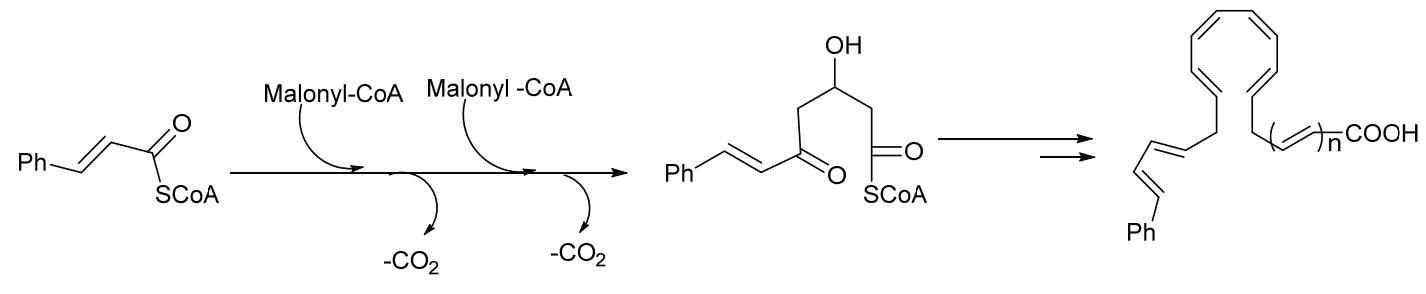

Scheme 1. General biosynthesis scheme of polyketides. 
Their biosyntheses from the polyketide contain two consecutive non-enzymatic electrocyclic reactions, followed by an intramolecular Diels-Alder reaction $[35,36,55]$. As a result of the whole reaction sequence, an open-chain compound is converted into a tetracyclic compound. The starting product contains a conjugated tetraene system, as well as a conjugated diene system. Thus, it already displays the $\pi$ electron systems required for the three pericyclic reactions; they are the two electrocyclizations and the Diels-Alder reaction $[35,36,55]$ (Scheme 2).

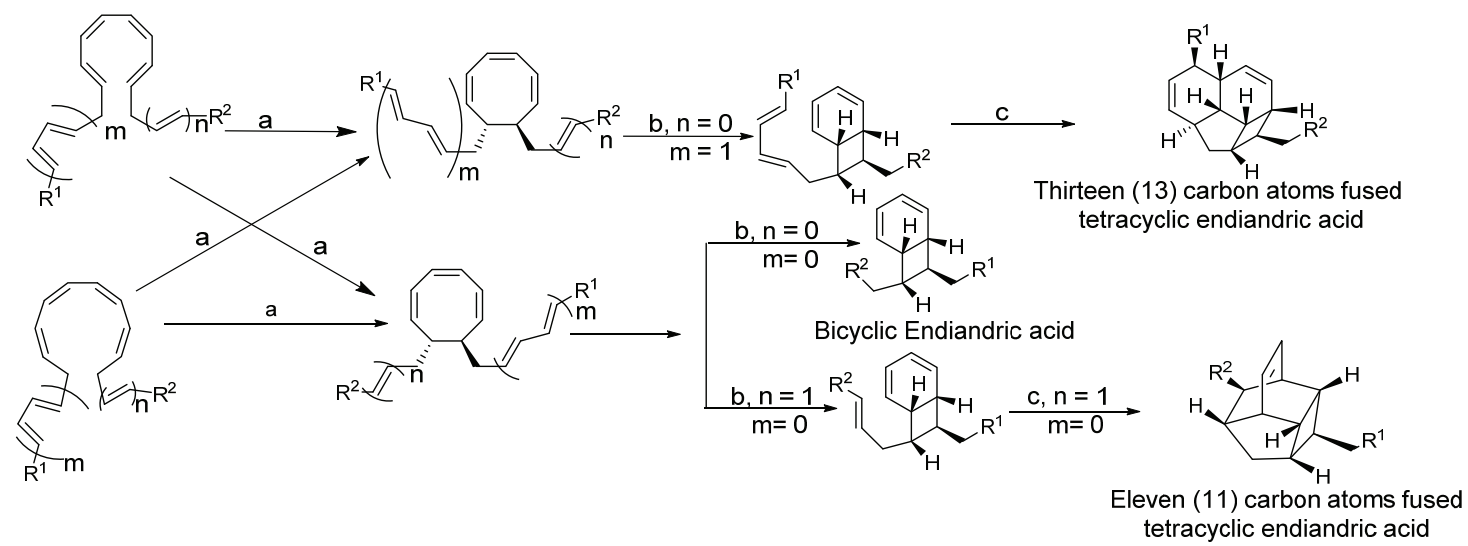

Scheme 2. General biosynthesis scheme of endiandric acid skeleton from polyketides.

a: Conrotatory $8 \pi$ electron cyclization; b: Disrotatory $6 \pi$ electron cyclization;

c: Diels-Alder cyclization.

Biogenesis of compounds of the kingianin family of natural products isolated from E. kingiana also involve a key Diels-Alder cycloaddition via a tandem $8 \pi / 6 \pi$ electrocyclisation. In fact, an arylpolyene undergoes a conrotatory $8 \pi e$ electrocyclization followed by a disrotatory $6 \pi e$ electrocyclization of the formed cyclooctatriene. Radical cation formal Diels-Alder reaction between two bicyclo[4.2.0]octa-2,4-diene monomers led to unique and complex pentacyclic derivatives as shown in the Scheme 3 [42].

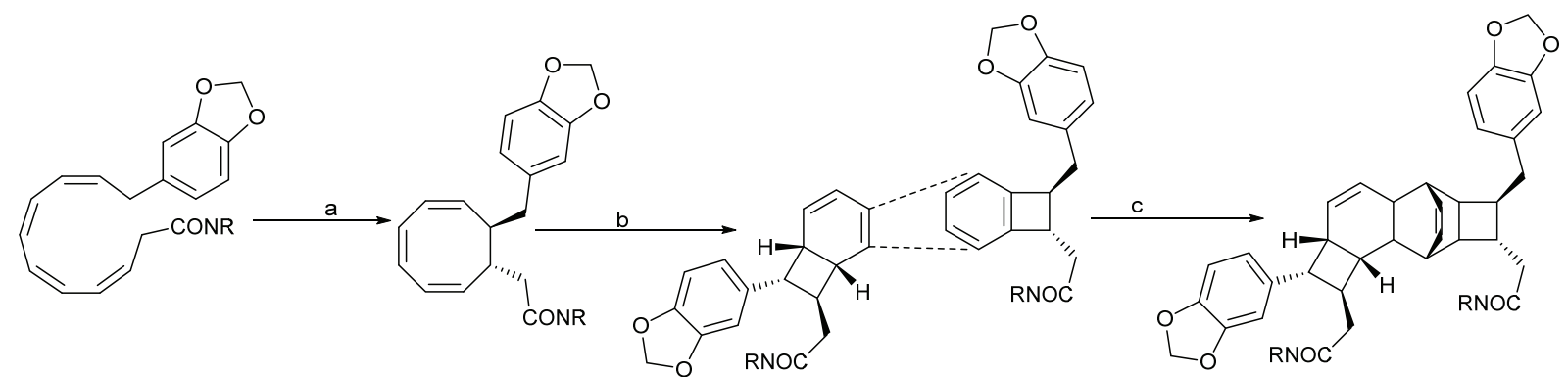

Scheme 3. General biosynthesis scheme of kingianin derivatives. a: Conrotatory $8 \pi$ electron cyclization; b: Disrotatory $6 \pi$ electron cyclization; c: Diels-Alder cyclization.

\subsubsection{Spectroscopic Characterization}

The structures of endiandric acid derivatives have mainly been proposed on the basis of modern spectroscopic methods and sometimes X-ray diffraction analysis. The majority of these compounds possess a $\mathrm{C}_{11}$ or $\mathrm{C}_{13}$ tetracyclic ring system along with a number of double bonds and substituents that display characteristic spectroscopic properties. 


\subsubsection{Mass Spectra}

The mass spectrum of endiandric acid derivatives with $\mathrm{C}_{13}$ fused tetracyclic ring system having $\mathrm{C}^{4}=\mathrm{C}^{5}$ double bond generally exhibits an unusual fragmentation pattern where a strong M-78 ion is often observed, due to the loss of a benzene moiety (Scheme 4) [35,36]. Most of the EI spectra exhibited base peaks at $\mathrm{m} / \mathrm{z}$ 172 or $\mathrm{m} / z 129$ like those of beilschmiedic acid A and C (Scheme 5). Other fragments corresponding to cleavage of the side chain and the dehydration have also been observed (Scheme 5) [17,19,20].

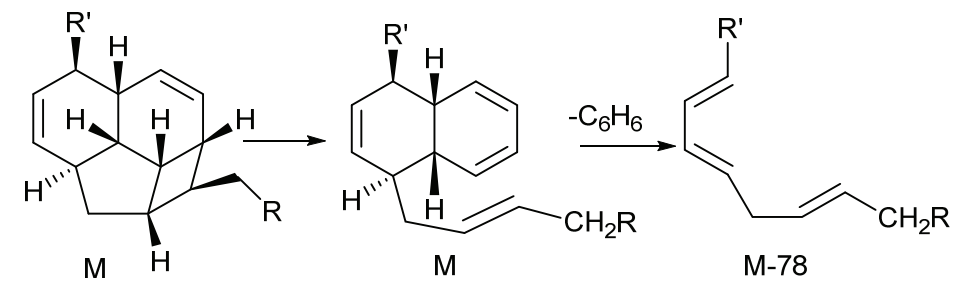

Scheme 4. Fragmentation encountered in some endiandric acid [21].

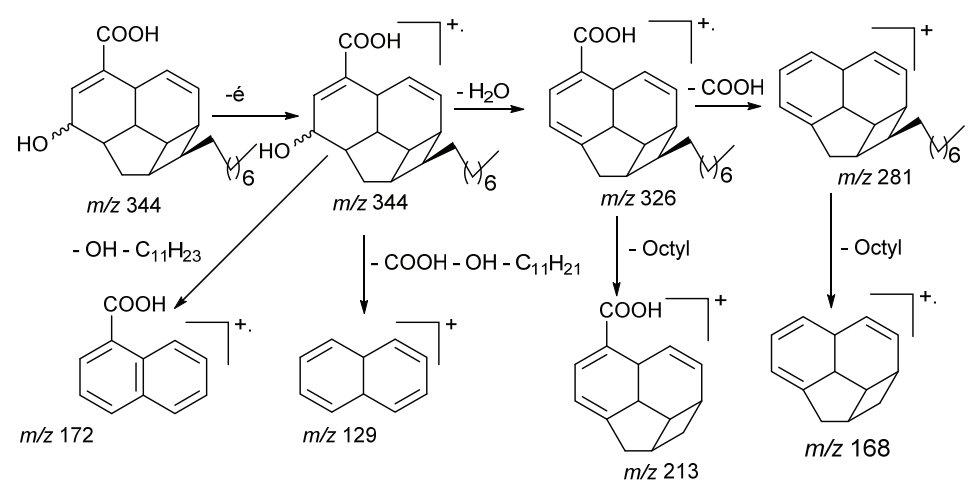

Scheme 5. Fragmentation mechanism of beilschmiedic acid A and C, EI, $70 \mathrm{eV}$ [17].

\subsubsection{NMR Spectra}

The ${ }^{1} \mathrm{H}-\mathrm{NMR}$ spectra of endiandric acid derivatives are complex and structure elucidation has to rely on a combination of $1 \mathrm{D}$ - and 2D-NMR techniques. ${ }^{1} \mathrm{H}-\mathrm{NMR}$ spectra of derivatives with skeleton $\mathbf{1}$ having $\mathrm{C}^{4}=\mathrm{C}^{5}$ double bond showed, among other peaks, a broad singlet of the methine proton $\mathrm{H}-7$ around $3.0 \mathrm{ppm}$, signals of one methylene protons [a doublet of triplet between $\delta 1.30-1.40(\mathrm{H}-2)$ and a doublet of doublet between 1.50-1.60 (H-2')], four cis olefinic protons at $\delta 6.10-6.30(\mathrm{dt}, \mathrm{H}-4), 5.50-5.80$ (dt, $J=9.7,3.0 \mathrm{~Hz}, \mathrm{H}-5$ ), 5.30-5.70 (brd, $J=9.8 \mathrm{~Hz}, \mathrm{H}-8$ ), and 5.60-5.70 (dt, $J=10.2,3.4 \mathrm{~Hz}, \mathrm{H}-9$ ). However, some signals are shifted when a double bond is present at C-5/C-6. In this case, a singlet of the olefinic proton $\mathrm{H}-5$ is observed between $\delta 6.80-7.50 \mathrm{ppm}$. This proton resonates around $6.20 \mathrm{ppm}$ when a ketone group is present at C-4. Endiandric acid derivatives with skeleton 2 exhibited, among other peaks, signals of methylene protons between $\delta 1.50-1.60(\mathrm{H}-6)$ and $1.80-1.90(1 \mathrm{H}, \mathrm{H}-6$ ') and two cis olefinic protons between $\delta 6.10-6.30(\mathrm{H}-10)$ and 6.20-6.30 (H-11). Those of compounds with skeleton 1 or 2 bearing a methylenedioxyphenyl moiety exhibited in addition an ABX system of olefinic of three protons at $\delta 6.60-6.66(1 \mathrm{H}, \mathrm{dd}, J=8.0,1.6 \mathrm{~Hz}), 6.64-6.90(1 \mathrm{H}, \mathrm{d}, J=1.6 \mathrm{~Hz})$ and $6.72-7.20$ $(1 \mathrm{H}, \mathrm{d}, J=8.0 \mathrm{~Hz})[17,19,20,22-24,41,44,48,49,52]$. Figure 1 summarises the range of ${ }^{1} \mathrm{H}-\mathrm{NMR}$ data of endiandric derivatives. 

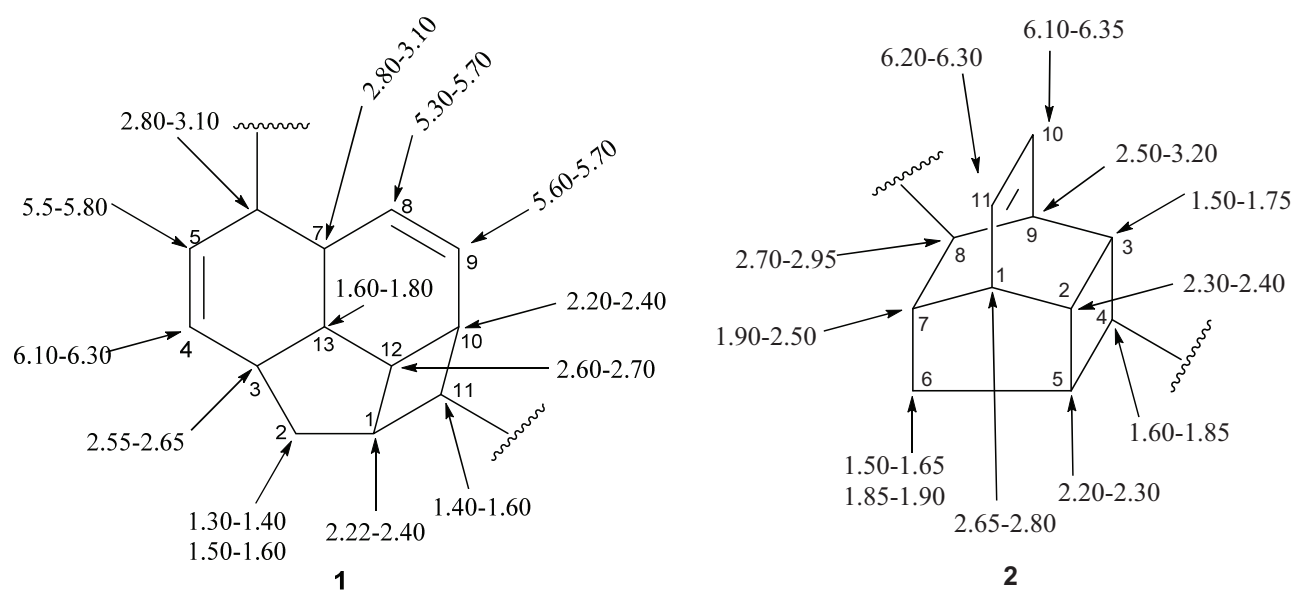

Figure 1. Range of ${ }^{1} \mathrm{H}-\mathrm{NMR}$ chemical shift of tetracyclic endiandric acid (skeleton 1 and 2) $[9,13,18-20,31,32,41,48,49,52]$.

${ }^{13} \mathrm{C}$-NMR spectroscopy is very helpful in the structure elucidation of endiandric acid derivatives since chemical shift databases can be used to search for similar patterns. In addition, ${ }^{13} \mathrm{C}-\mathrm{NMR}$ chemical shifts tend to be more reproducible and are less influenced by solvent, temperature or $\mathrm{pH}[56,57]$. The ${ }^{13} \mathrm{C}-\mathrm{NMR}$ spectrum of tetracyclic endiandric acids exhibits among other signals 11 or 12 methines and one to two methylenes for the basic skeletons [21-24,33,34,44]. The signals of methines (C-1, C-3, C-7, $\mathrm{C}-10, \mathrm{C}-11, \mathrm{C}-12, \mathrm{C}-13)$ and the methylene $\mathrm{C}-2$ in derivatives with skeleton 1 and those of methines (C-1, C-2, C-3, C-4, C-5, C-7, C-8, C-9) and the methylene C-6 in compounds with skeleton 2 are characteristic for the tetracyclic endiandric acids $[9,14,21,34,44]$. The chemical shift of the carboxy group at C-6 in compounds with skeleton 1 helps to confirm the location of the double bond in cycle D. In fact, when the double bond is $\mathrm{C}^{5}=\mathrm{C}^{6}$, the carbon of the carboxyl group appears at around $170 \mathrm{ppm}$. In case of $C^{4}=C^{5}$ double bond, it appears at between 175 and 181 ppm [9,13,14,18-20,30,31,44,48,52]. However, some signals are shifted when the double bond is $C^{5}=C^{6}$. In this case, the olefinic carbon $C-5$ appears at around $141 \mathrm{ppm}$ in compound bearing a carboxylic group at C-6. This chemical carbon can shift to 145 ppm when hydroxyl is present at C-4 [9,13,18-20,31,32,48,52]. The chemical shift range (in ppm) of carbons of the tetracyclic endiandric skeletons are given in Figure 2.
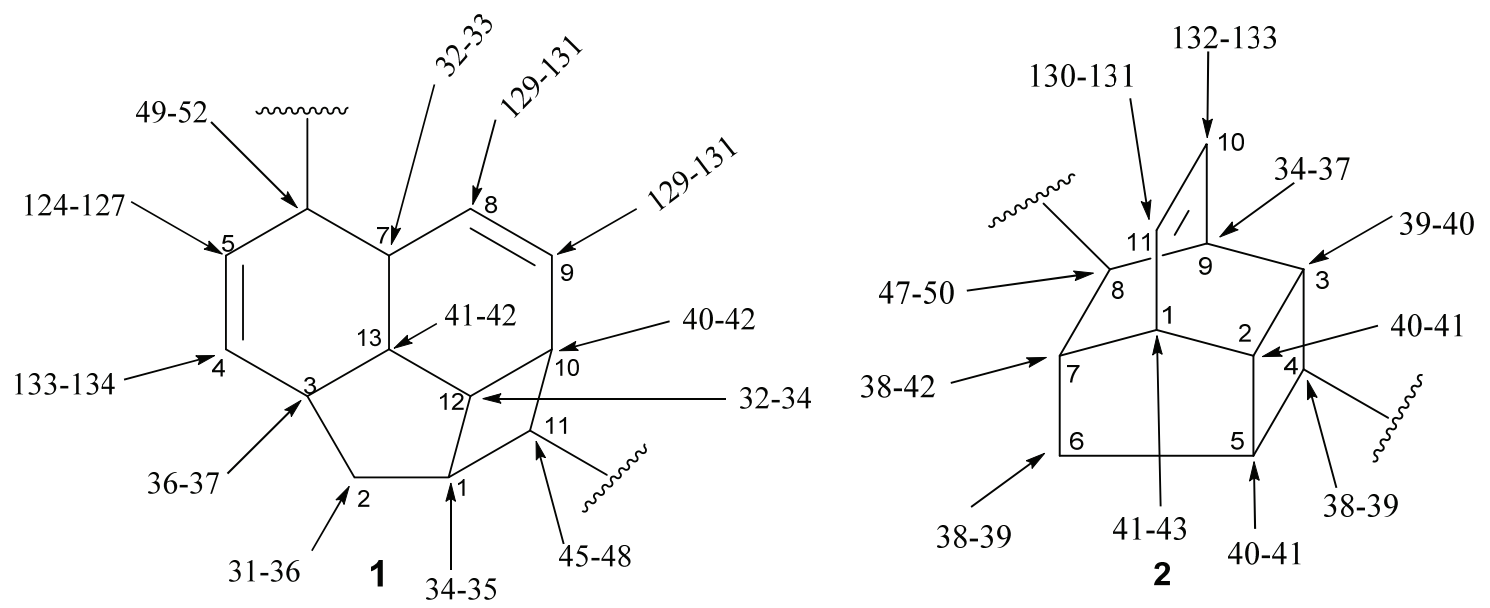

Figure 2. Range of ${ }^{13} \mathrm{C}$ NMR chemical shift of the tetracyclic endiandric acid (skeleton $\mathbf{1}$ and $\mathbf{2}$ ). 


\subsection{Alkaloids and Amides}

Plants of Lauraceae are rich sources of bioactive alkaloids [58-65]. The majority of alkaloids isolated from Beilschmiedia species possess aporphine skeletons (71, Table 3) or benzylisoquinoline (72) skeletons.
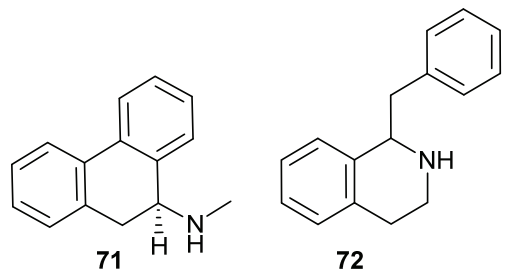

(+)-Predicentrine (73), which was first prepared by $O$-methylation of boldine (74), was isolated together with norpredicentrine (75) from the leaves of B. podagrica. Three aporphine alkaloids, isocorydine (76), glaucine (77), and $(+)-N$-methyllindcarpine (78) were obtained after subsequent investigation of the leaves of the same plant while laurelliptine (79) and isoboldine (80) were obtained from the bark [66,67]. Laurelliptine (79) was also obtained from the bark of B. elliptica together with the pale pink needles of isoboldine (80) [67,68]. Isoboldine (80) was identified as the major alkaloid from berries of B. tawa [46].

The phytochemical investigation of the leaves of $B$. alloiophylla has resulted in the isolation of the alkaloids 2-hydroxy-9-methoxyaporphine (81), laurotetanine (82), boldine (74), isoboldine (80), asimilobine (83) [29].

Table 3. Substitution pattern of aporphine alkaloids 73-86.

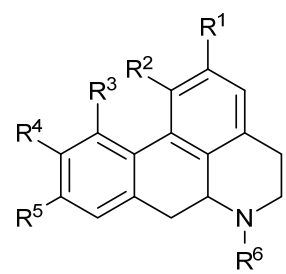

\begin{tabular}{|c|c|c|c|c|c|c|c|c|}
\hline Compounds & $\mathbf{R}^{1}$ & $\mathbf{R}^{2}$ & $\mathbf{R}^{3}$ & $\mathbf{R}^{4}$ & $\mathbf{R}^{5}$ & $\mathbf{R}^{6}$ & Sources & Ref. \\
\hline$(+)$-Predicentrine $(73)$ & $\mathrm{OH}$ & $\mathrm{OMe}$ & $\mathrm{H}$ & $\mathrm{OMe}$ & $\mathrm{OMe}$ & $\mathrm{Me}$ & B. podagrica & {$[66]$} \\
\hline Boldine (74) & $\mathrm{OH}$ & $\mathrm{OMe}$ & $\mathrm{H}$ & $\mathrm{OMe}$ & $\mathrm{OH}$ & $\mathrm{Me}$ & B. alloiophylla, B. kunstleri & [29] \\
\hline Norpredicentrine (75) & $\mathrm{OH}$ & $\mathrm{OMe}$ & $\mathrm{H}$ & $\mathrm{OMe}$ & $\mathrm{OMe}$ & $\mathrm{H}$ & B. podagrica & {$[66]$} \\
\hline (+)-Isocorydine (76) & $\mathrm{OMe}$ & $\mathrm{OMe}$ & $\mathrm{OH}$ & $\mathrm{OMe}$ & $\mathrm{H}$ & $\mathrm{Me}$ & B. podagrica & {$[66]$} \\
\hline$(+)$-Glaucine $(77)$ & $\mathrm{OMe}$ & $\mathrm{OMe}$ & $\mathrm{H}$ & $\mathrm{OMe}$ & $\mathrm{OMe}$ & $\mathrm{Me}$ & B. podagrica & {$[66]$} \\
\hline$(+)-N$-methylindcarpine (78) & $\mathrm{OH}$ & $\mathrm{OMe}$ & $\mathrm{OH}$ & $\mathrm{OMe}$ & $\mathrm{H}$ & $\mathrm{Me}$ & B. podagrica & {$[66]$} \\
\hline (+)-Laurelliptine (79) & $\mathrm{OMe}$ & $\mathrm{OH}$ & $\mathrm{H}$ & $\mathrm{OMe}$ & $\mathrm{OH}$ & $\mathrm{H}$ & B. podagrica & {$[67,68]$} \\
\hline$(+)$-Isoboldine $(\mathbf{8 0})$ & $\mathrm{OMe}$ & $\mathrm{OH}$ & $\mathrm{H}$ & $\mathrm{OMe}$ & $\mathrm{OH}$ & $\mathrm{Me}$ & B. alloiophylla, B. tawa & {$[29,46]$} \\
\hline 2-Hydroxy-9-methoxy aporphine (81) & $\mathrm{OH}$ & $\mathrm{H}$ & $\mathrm{H}$ & $\mathrm{H}$ & $\mathrm{OMe}$ & $\mathrm{Me}$ & B. alloiophylla & {$[29]$} \\
\hline$(+)$-Laurotetanine $(\mathbf{8 2})$ & $\mathrm{OMe}$ & $\mathrm{OMe}$ & $\mathrm{H}$ & $\mathrm{OMe}$ & $\mathrm{OH}$ & $\mathrm{H}$ & B. alloiophylla, B. kunstleri & {$[29,31]$} \\
\hline$(-)$-Asimilobine $(\mathbf{8 3})$ & $\mathrm{OH}$ & $\mathrm{OMe}$ & $\mathrm{H}$ & $\mathrm{H}$ & $\mathrm{H}$ & $\mathrm{H}$ & B. alloiophylla & {$[29]$} \\
\hline$(+)$-Norboldine $(\mathbf{8 4})$ & $\mathrm{OH}$ & $\mathrm{OMe}$ & $\mathrm{H}$ & $\mathrm{OMe}$ & $\mathrm{OH}$ & $\mathrm{H}$ & B. kunstleri & {$[31]$} \\
\hline$(+)$-Cassithicine $(\mathbf{8 5})$ & \multicolumn{2}{|c|}{$\mathrm{O}-\mathrm{CH}_{2}-$} & $\mathrm{H}$ & $\mathrm{OMe}$ & $\mathrm{OH}$ & $\mathrm{Me}$ & B. kunstleri & {$[31]$} \\
\hline Nornuciferine (86) & $\mathrm{OMe}$ & $\mathrm{OMe}$ & $\mathrm{H}$ & $\mathrm{H}$ & $\mathrm{H}$ & $\mathrm{H}$ & B. kunstleri & {$[31]$} \\
\hline
\end{tabular}


Tetracyclic alkaloids with morphine skeleton (+)-oreobeiline $(\mathbf{8 7})$ and $(+)-6$-epioreobeiline $(\mathbf{8 8})$ together with other aporphine alkaloids secoboldine (89), liriodenine (90) and (S)-3-methoxynordomesticine (91) were also isolated by Mollataghi and colleagues from B. alloiophylla [29]. Two of these alkaloids, (+)oreobeiline $(\mathbf{8 7})$ and $(+)$-6-epioreobeiline $(\mathbf{8 8})$ were first isolated by Tillequin and colleagues from the wood of B. oreophila [47].

The benzylisoquinoline alkaloids O,O-dimethylannocherin A (92), (6,7-dimethoxy-4-methylisoquinolinyl)(4'-methoxyphenyl)methanone (93), (6,7-dimethoxy-1-isoquinolinyl)-(4'-methoxyphenyl)methanone (94), ( \pm )- $N$-norarmepavine (95), (R)-(-)-armepavine (96), $O, O$-dimethylcoclaurine $(97)$ and $O$-methylvelucryptine (98) were isolated from the leaves of B. brevipes [45]. One compound of this class, (+)-N-dimethylphyllocryptine (99), was obtained from B. alloiophylla [29].
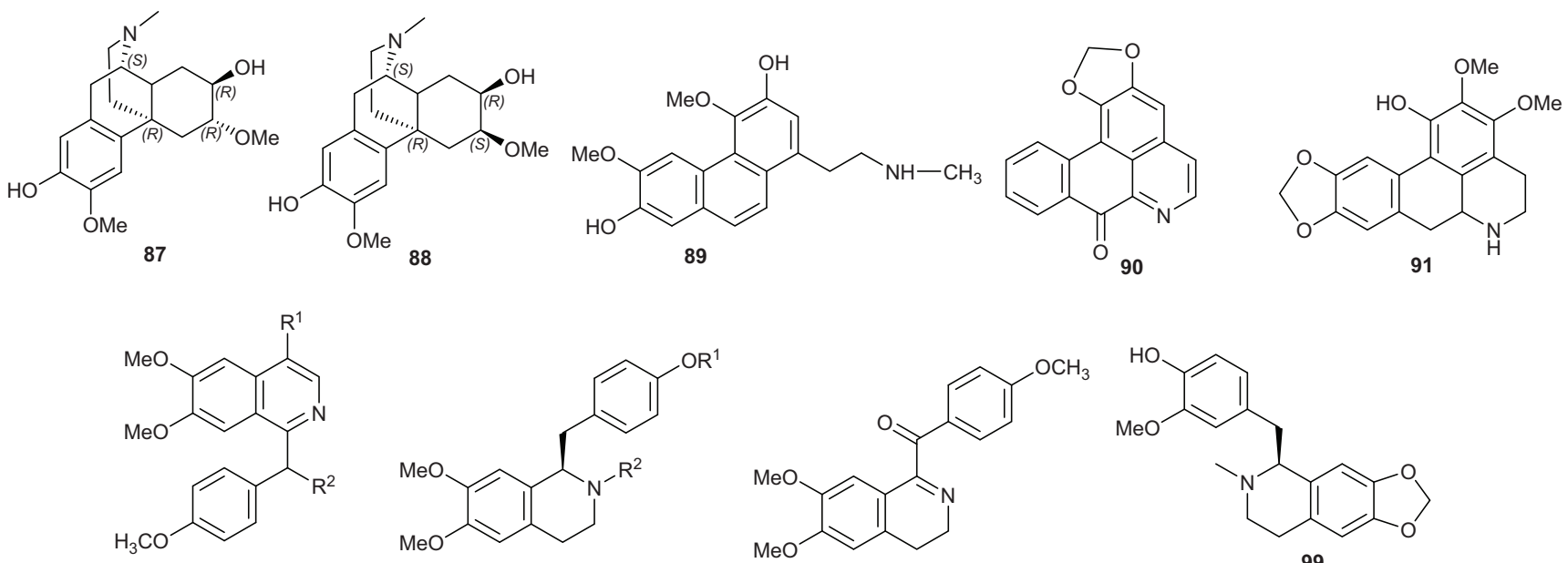

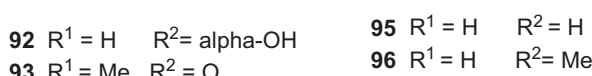
$94 R^{1}=H \quad 97 R^{1}=M e \quad R^{2}=H$

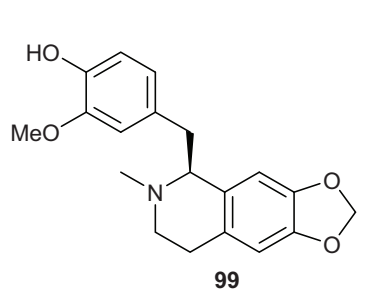

98

Dehatrine (100), an antimalarial bisbenzylisoquinoline alkaloid, was isolated in the frame of a bioguided investigation on antiplasmodial activity of the wood of the Indonesian medicinal plant $B$. madang [12].

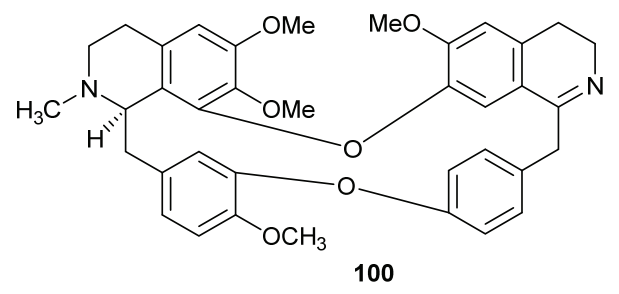

The phytochemical investigation of the leaves of B. kunstleri afforded several alkaloids: $(+)-N$ methylisococlaurine (101), (+)-cassythicine (85), $(+)$-laurotetanine $(\mathbf{8 2}),(+)$-boldine $(\mathbf{7 4}),(-)$-pallidine (102), (+)-nornuciferine (86), noratherosperminine (103), (+)- $N$-dimethylphyllocaryptine (99), (-)isocaryachine (104), and the amide (-)-kunstleramide (105) [29,30]. Other amides, zanthonamide (106) and pipyahyine (107) have been isolated from the stem bark of B. zenkeri by Lenta and colleagues [18]. Additionally, a cyclostachine acid derivative obscurine (108) was isolated from the stem of B. obscura [28]. From the stem bark of $B$. erythrophloia three amides, $N$-trans-feryoltyramine (109), $N$-trans-feryoloctopamine (110) and beilschamide (111), were isolated [69]. 

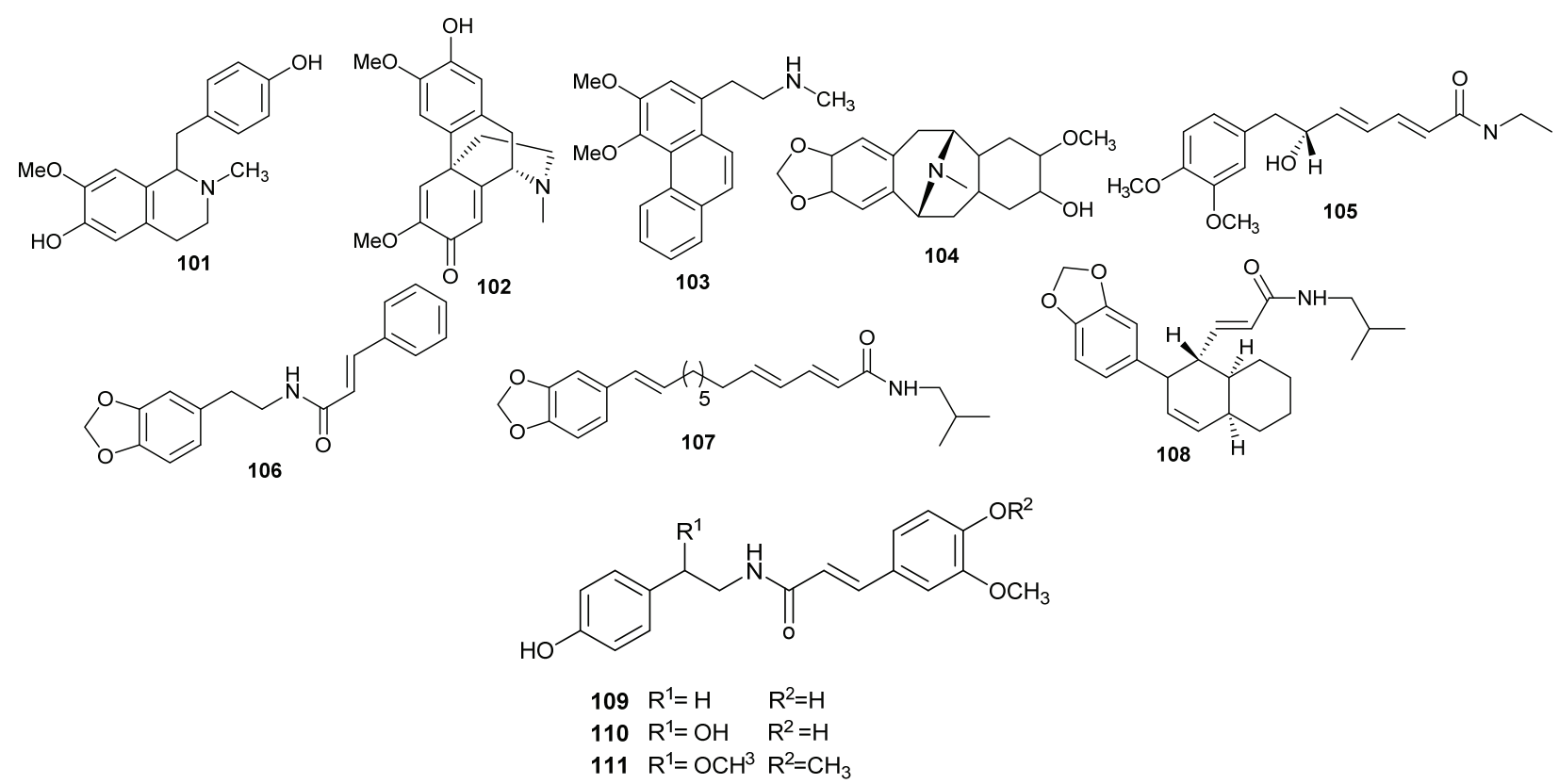

The chemical investigation of the bark of E. kingiana led to the isolation of a series of polyketides as a racemic mixtures, having each an amide function and named kingianins $\mathrm{A}-\mathrm{N}(\mathbf{1 1 2}-\mathbf{1 2 5})$. These amides possess an unusual pentacyclic carbon skeleton and was described for the first time in nature by Leverrier and coll. [42,43]. Seemingly, no alkaloids have been reported to date for the genus Endiandra.
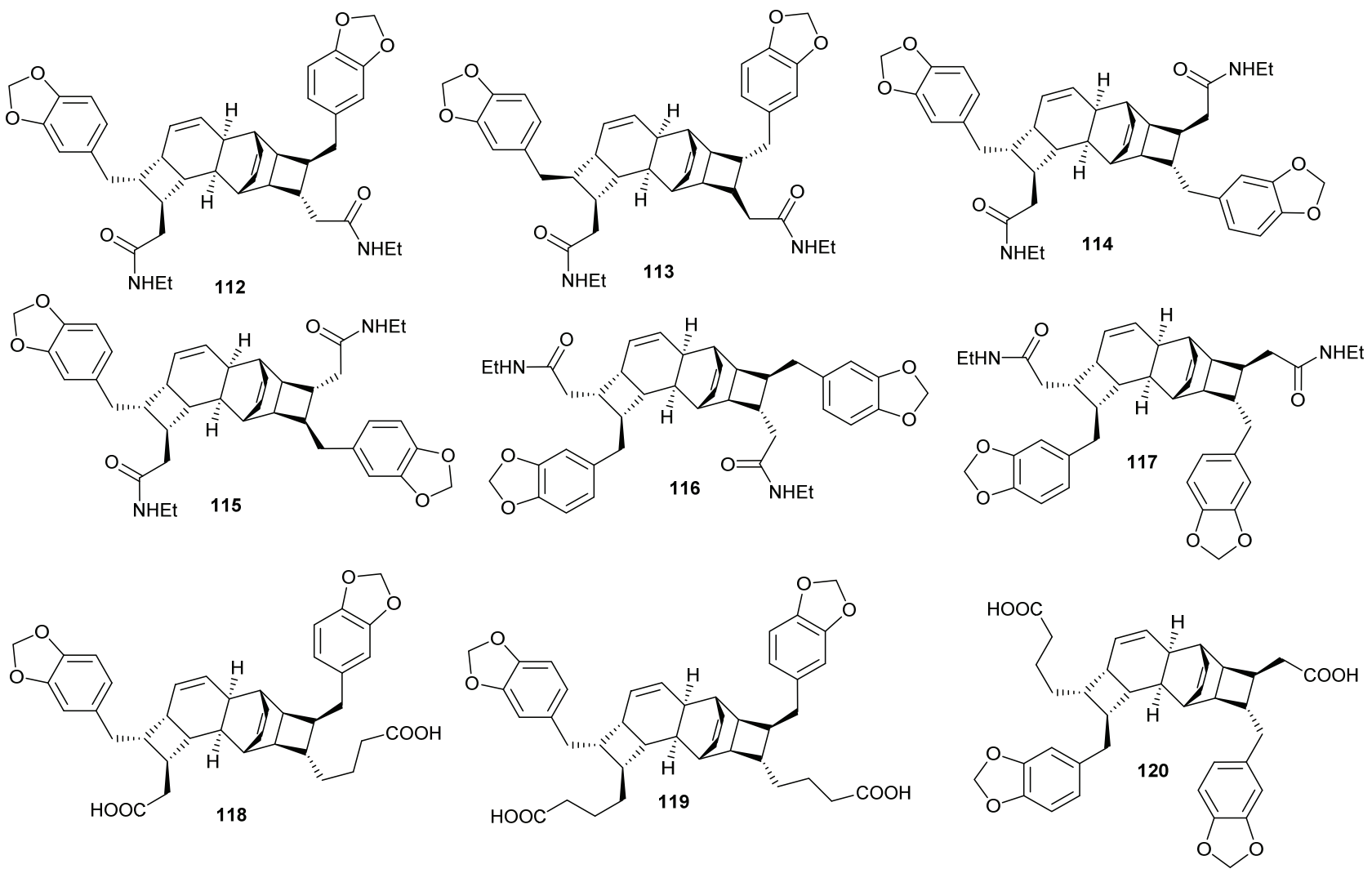


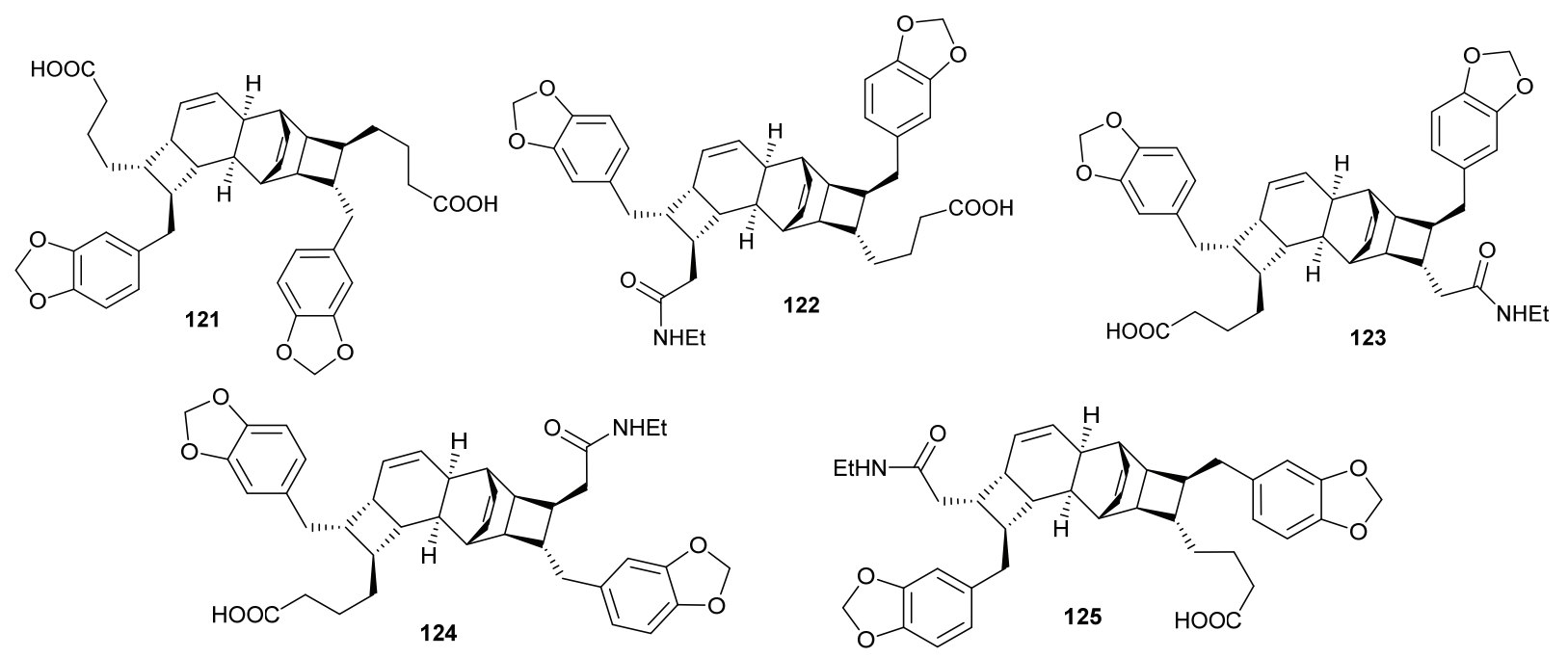

\subsection{Lignans and Neolignans}

Plants of the Lauraceae family are sources of bioactive lignans [70-72]. The majority of lignans and neolignans isolated from the genus Beilschmiedia were obtained from the species B. tsangii. The investigation of the roots, leaves and stem of this species afforded the lignans ambo- $\left(7 R, 8 R, 7^{\prime} R, 8^{\prime} R\right)$ -

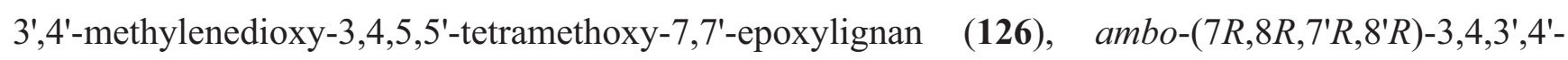
dimethylenedioxy-5,5'-dimethoxy-7,7'-epoxylignan (127), beilschminol A (128), beilschminol B (129) together with other polymethylated derivatives $4 \alpha, 5 \alpha$-epoxybeilschmin A (130), $4 \alpha, 5 \alpha$-epoxybeilschmin B (131), beilschmin D (132), beilschmin A (133), beilschmin B (134), beilschmin C (135), ambo-(7S, $\left.8 S, 7^{\prime} R, 8^{\prime} R\right)-3,3^{\prime}, 4,4^{\prime}, 5,5^{\prime}$-hexamethoxylignan (136), and three 1-phenylbutyl benzoates, tsangin A (137), B (138), and C (139) [22,23,25,26].

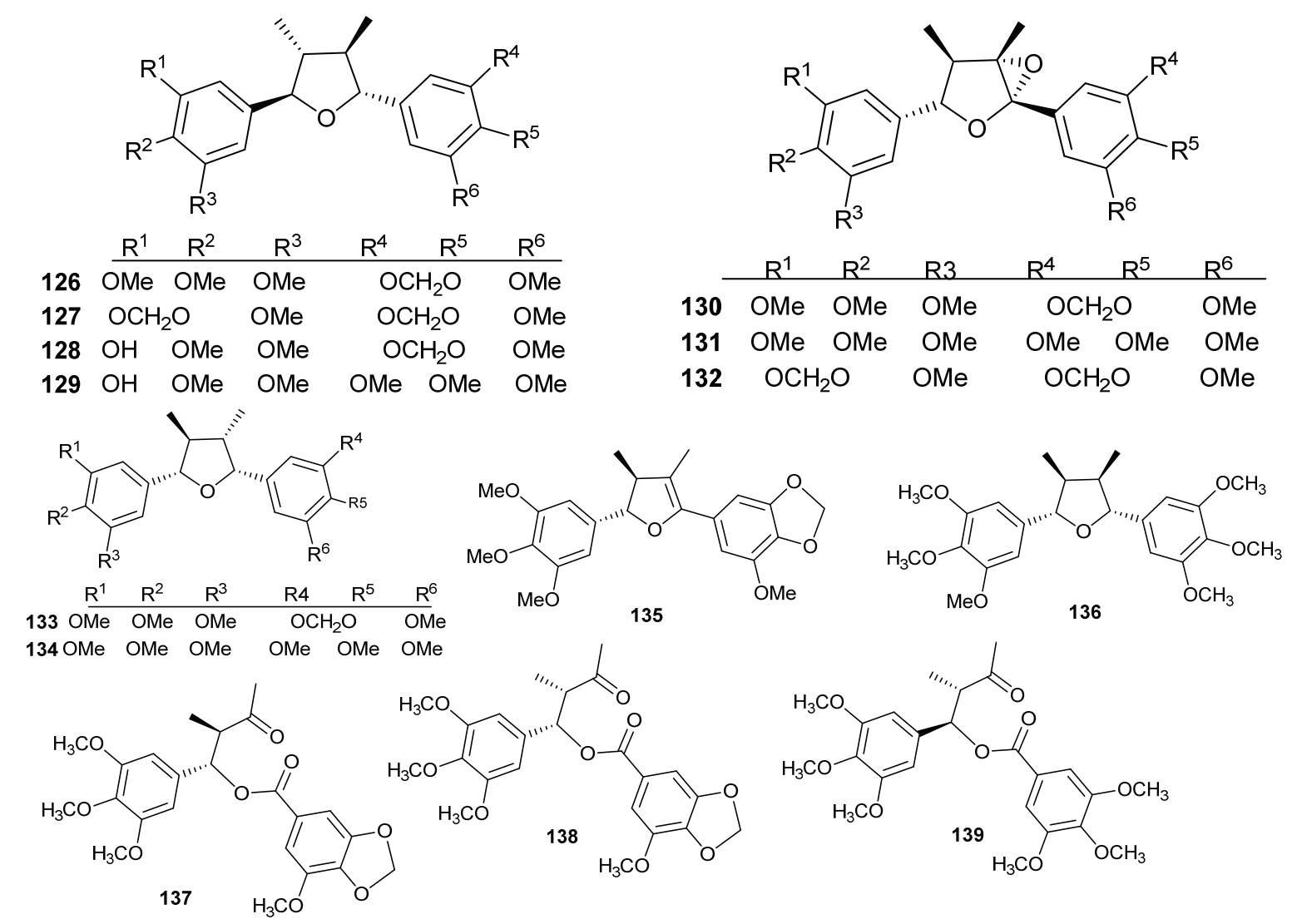


The investigation of the dichloromethane extract of the leaves of B. kunstleri yielded an antioxidant neolignan, (+)-kunstlerone (140) [30].

Magnolol (141), an antibacterial neolignan, was isolated from different Endiandra species specifically E. xanthocarpa, B. volckii, E. bassaphila, E. leptodendron, E. monothyra and E. wolfii [40]. From the extracts of the leaves of E. xanthocarpa and E. palmerstonii, sesamin (142), a lignan known to be a phytoestrogen, was isolated [40].

From the roots of E. anthropophagorum the cyclobutane lignans, endiandrin A (143) and endiandrin B (144), together with (-)-dihydroguaiaretic acid (145) and nectandrin B (146) were isolated. This type of lignan containing a cyclobutane moiety is rare in nature. Endiandrin A (143) and B (144) represent only the 23 rd and 24th naturally occurring cyclobutane lignans [32,33].
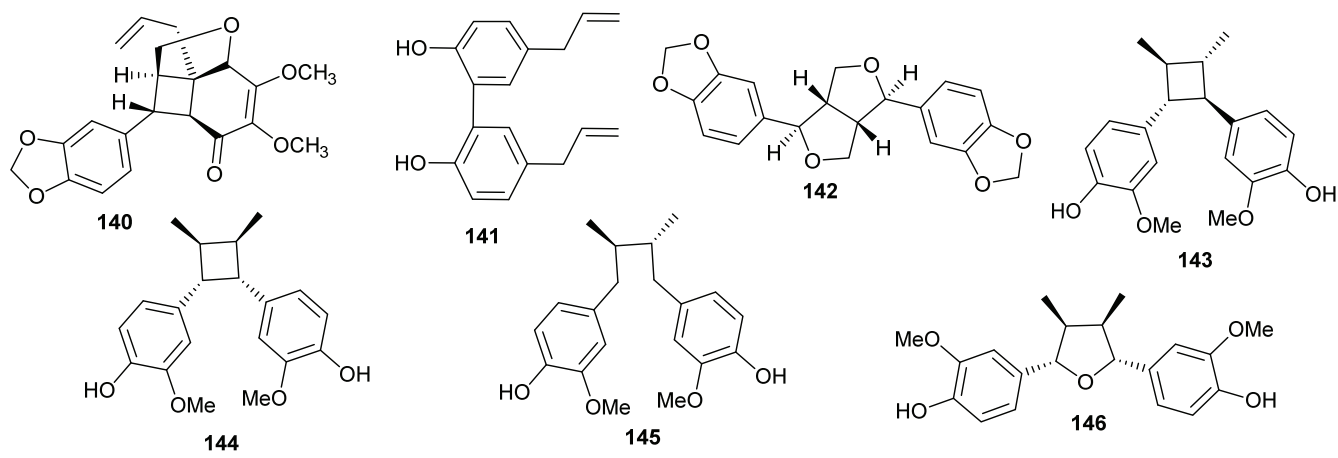

\subsection{Flavonoids and Chalcones}

Flavonoids have been isolated from many species of Lauraceae family [73]. However, this class of secondary metabolites has not been reported to date in Endiandra. They were obtained only from two species of Beilschmiedia: B. miersii and B. zenkeri. The rare quercetin-5-methyl ether known as azaleatin (147) was isolated from the leaves of $B$. miersii together with quercetin (148), quercetrin (149), isoquercetrin (150), afzeloside (151) and mikwelianin (152) [21].

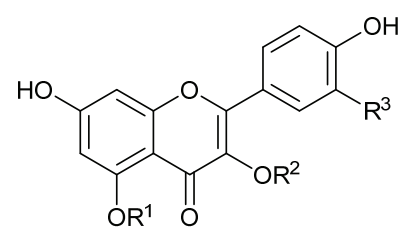

\begin{tabular}{clll} 
& $\mathrm{R}^{1}$ & $\mathrm{R}^{2}$ & $\mathrm{R}^{3}$ \\
\hline 147 & $\mathrm{CH}_{3}$ & $\mathrm{OH}$ & $\mathrm{OH}$ \\
148 & $\mathrm{H}$ & $\mathrm{H}$ & $\mathrm{OH}$ \\
149 & $\mathrm{H}$ & Rha & $\mathrm{OH}$ \\
150 & $\mathrm{H}$ & $\mathrm{Glc}$ & $\mathrm{OH}$ \\
151 & $\mathrm{H}$ & Rha & $\mathrm{H}$ \\
152 & $\mathrm{H}$ & $\mathrm{GlcA}$ & $\mathrm{OH}$
\end{tabular}

Five methoxylated flavonoid derivatives, (2S,4R)-5,6,7-trimethoxyflavan-4-ol (153), $(2 S, 4 R)-4,5,6,7$ tetramethoxyflavan (154), beilschmieflavonoid A (155), beilschmieflavonoid B (156), and 5-hydroxy-7,8dimethoxyflavanone (157), were isolated from the stem bark of B. zenkeri [18]. Beilschmieflavonoids A (155) and $\mathrm{B}(\mathbf{1 5 6})$ possess an unusual $\mathrm{C}_{4}-\mathrm{O}-\mathrm{C}_{4}$ " linkage that has been found only in a biflavonoid isolated from Tephrosia tepicana (Leguminosae) [74]. Only two chalcones, 2',6'-dihydroxy-4-isoprenyloxy3,4-(3"',3"'-dimethylpyrano)chalcone (158) and 4,2',6'-trihydroxy-3',4'-methylenedioxy-3-isopent-2enylchalcone (159), were reported from the genus Beilschmiedia and precisely from the Brazilian species Beilschmiedia tovarensis [13]. No chalcone has been reported from the genus Endiandra. 

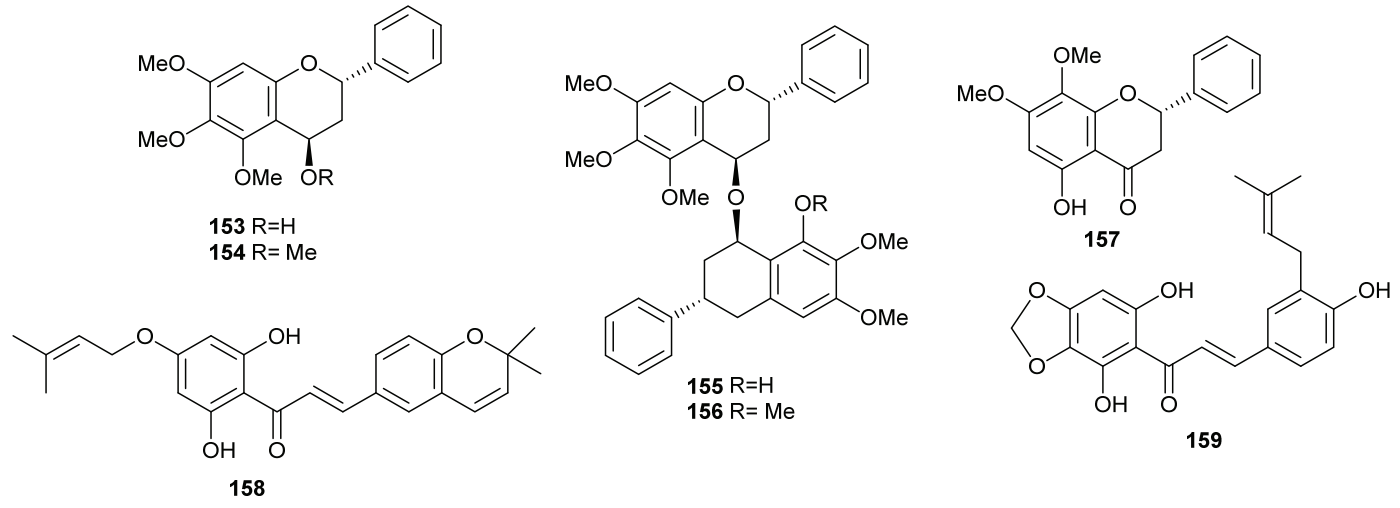

\subsection{Benzene Derivatives}

Benzene compounds have been isolated mostly from plants of the Beilschmiedia genus. Some of these compounds are benzaldehyde derivatives such as vanillin (160), $p$-hydroxybenzaldehyde (161), 3,4,5-trimethoxybenzaldehyde (162), isolated from the root and stem of B. tsangii [22,23,25]. Vanillin (160) was also isolated from the stem bark of B. erythrophloia [69]. Sarisan (163), an insect repelling allyl benzenoid, was isolated from the leaves of $B$. miersii [27,50]. The benzopyran oligandrol (164), was isolated from the bark of B. oligandra [40]. Its methylated derivative, oligandrol methyl ether (165), was obtained from the root of $B$. erythrophloia together with the benzenoids farnesylol (166) and $\alpha$-tocopheryl quinone (167) [41,49]. Compound 167 was also isolated from the stem of $B$. tsangii and B. erythrophloia $[25,69]$. Another benzopyran derivative, $\alpha$-tocopherol (168), was isolated from the roots of $B$. tsangii.

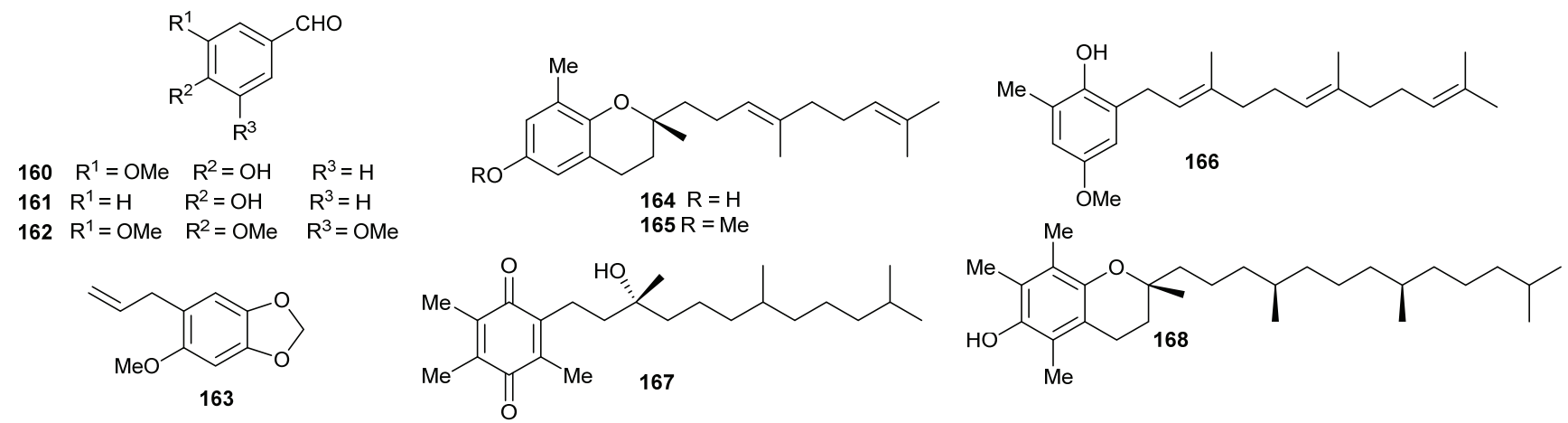

\subsection{Terpenoids}

Sesquiterpenes and triterpenoids are two classes of terpenoids mostly isolated from plants of Beilschmiedia and Endiandra genera.

The triterpenoids ursolic acid (169) and squalene (170) were isolated from the roots and leaves of $B$. tsangii, respectively [22,26]; lupeol (171) and 3-O-acetyl betulinic acid (172) were obtained from the roots of $B$. erythrophloia; betulinic acid (173) from the stem bark of $B$. zenkeri $[18]$ and $\beta$-amyrone (174) from B. alloiophylla [29]. 


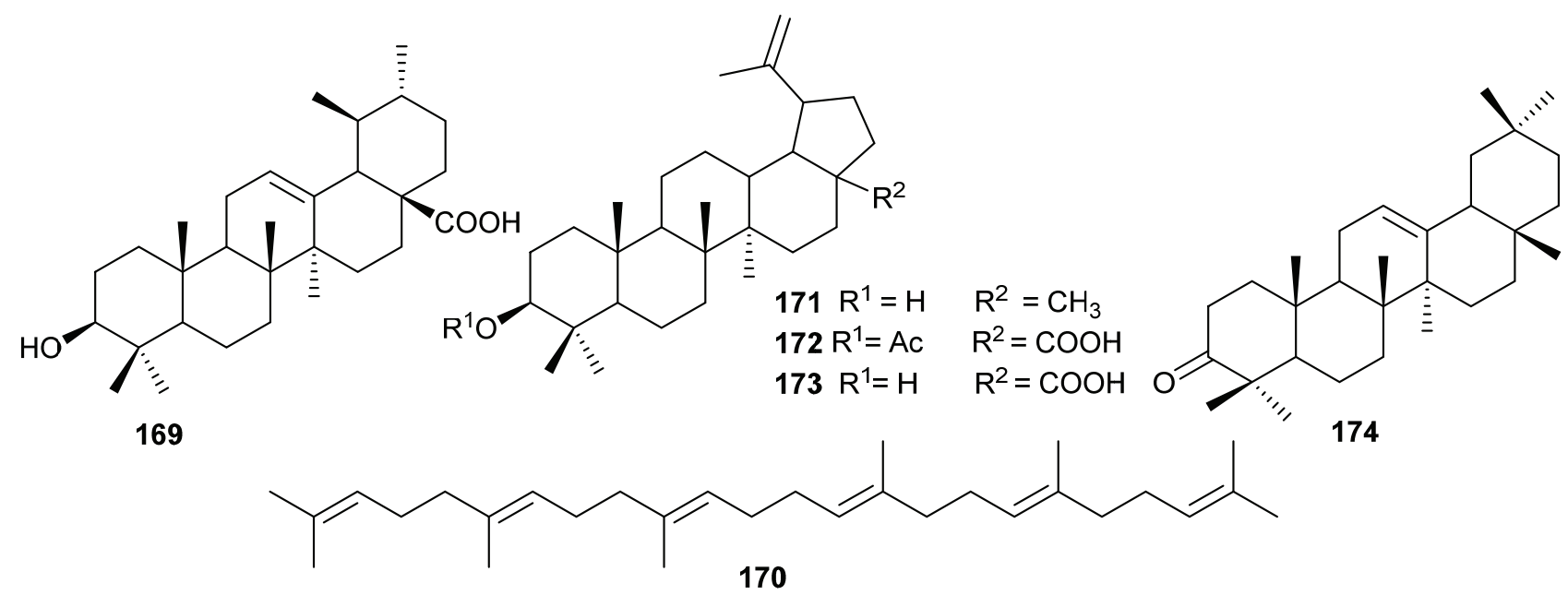

The skeletons of sesquiterpenes isolated from both genera are different. They are either bi-, tri-, or polycyclic with different degrees of oxidation. From the roots of $B$. tsangii, (+)-5-hydroxybarbatenal (175), (4R,5R)-4,5-dihydroxycaryophyll-8(13)-ene (176), octahydro-4-hydroxy-3 $\alpha$-methyl-7-methylene- $\alpha-(1$ methylethyl)-1H-Indene-1-methanol (177), eudesm-4(15)-ene-1 $\beta, 6 \alpha$-diol (178), were isolated [22]. From its stem, 2,6,11-trimethyldodeca-2,6,10-triene (179) was obtained [25]. Suberosol B (180) was obtained from the roots of $B$. erythrophloia and $(+)$ - $\alpha$-curcumene (181) from the leaves of E. xanthocarpa [40]. The investigation of the leaves of another Endiandra species, E. baillonii also provided the sesquiterpenes ishwarane (182), $\alpha$-copaene (183), cis/trans-calamanene (184), and (+)- $\alpha$-curcumene (181) [40].

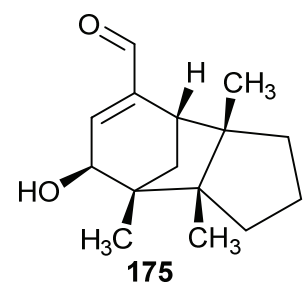<smiles>C=C1CCC2O[C@]2(C)[C@H](O)C[C@@H]2[C@@H]1CC2(C)C</smiles>

180<smiles>C[C@@H]1C[C@H]2[C@@H](O)CCC(=[P+2])[C@@H]2CC[C@@]1(C)O</smiles><smiles>CC(C)=CCC[C@H](C)c1ccc(C)cc1</smiles><smiles>C=C1CC[C@H](O)[C@H]2CC[C@H]([C@H](O)C(C)C)C12</smiles>

177<smiles>CC1CCCC23CC(C)(CC2C1)CC3(C)C</smiles>

182<smiles>C=C1CC[C@@H](O)[C@]2(C)CC[C@H](C(C)C)[C@H](O)[C@H]12</smiles><smiles>CC=C(C)CCC=C(C)C</smiles>

179

Sesquiterpenes and monoterpenes have been identified as the major constituents of the essential oils obtained from species of the genus Beilschmiedia (Table 4). 
Table 4. Chemical composition of essential oils of Beilschmiedia species.

\begin{tabular}{|c|c|}
\hline Species & Major Constituents \\
\hline B. miersii & $\begin{array}{l}\text { Leaf oil: Germacrene } \mathrm{D}(\mathbf{1 8 5}, 24.8 \%), \alpha \text {-terpinene }(\mathbf{1 8 6}, 10 \%), \gamma \text {-curcumene }(\mathbf{1 8 7}, 9.6 \%) \text {, } \\
\text { 1-octen-3-yl acetate }(\mathbf{1 8 8}, 8.2 \%),(\mathrm{E})-\beta \text {-ocimene }(\mathbf{1 8 9}, 6.4 \%)[51]\end{array}$ \\
\hline B. tarairie & Leaf oil: $\alpha$-terpinene $(\mathbf{1 8 6}, 17.8 \%), \beta$-pinene $(\mathbf{1 9 0}, 9.4 \%)$, germacrene D (185) [75] \\
\hline B. brenesii & $\begin{array}{l}\text { Leaf oil: germacrene } \mathrm{D}(\mathbf{1 8 5}, 19.3,(E) \text {-caryophyllene }(\mathbf{1 9 1}, 13.4 \%), \text {-undecanone }(\mathbf{1 9 2}, 12.8 \%) \text {, } \\
\alpha \text {-copaene }(\mathbf{1 8 3}, 9.0) \text {, trans-2-hexanal }(\mathbf{1 9 3}, 8.8 \%)[76]\end{array}$ \\
\hline B. costaricensis & Leaf oil: $\alpha$-bisabolol (194, 72.1\%), Cis 2-hexenol (195, 5.2\%), $\alpha$-terpinene $(\mathbf{1 8 6}, 3.0 \%)[76]$ \\
\hline B. alloiophylla & $\begin{array}{l}\text { Leaf oil: germacrene } \mathrm{D}(\mathbf{1 8 5},(18.9) \text {, cis- } \beta \text {-ocimene }(\mathbf{1 9 6}, 18.8 \%), \beta \text {-pinene }(\mathbf{1 9 0}, 3.0 \%) \text {, } \\
\text { trans- } \beta \text {-ocimene }(\mathbf{1 8 9}, 9.3 \%) \text {, bicyclogermacrene }(\mathbf{1 9 7}, 9.1 \%)[77]\end{array}$ \\
\hline B. talaranensis & Leaf oil: germacrene D $(\mathbf{1 8 5}, 54.9 \%), \beta$-caryophyllene $(\mathbf{1 9 1}, 14.8 \%), \alpha$-terpinene $(\mathbf{1 8 6}, 3.6 \%)[77]$ \\
\hline B. madang & $\begin{array}{l}\text { leaf oil: } \delta \text {-cadinene }(\mathbf{1 9 8}, 17.0 \%), \beta \text {-caryophyllene }(\mathbf{1 9 1}, 10.3 \%), \alpha \text {-cubebene }(\mathbf{1 9 9}, 11.3 \%) \text {, and } \\
\alpha \text {-cadinol }(\mathbf{2 0 0}, 5.8 \%)[78] \text {; } \\
\text { bark oil: } \delta \text {-cadinene }(\mathbf{1 9 5}, 20.5 \%), \beta \text {-caryophyllene }(\mathbf{1 9 1}, 6.7 \%), \alpha \text {-cubebene }(\mathbf{1 9 9}, 15.6 \%) \text {, and } \\
\alpha \text {-cadinol }(\mathbf{2 0 0}, 10.6 \%)[78]\end{array}$ \\
\hline $\begin{array}{l}\text { B." chancho } \\
\text { chancho" }\end{array}$ & $\begin{array}{l}\text { Leaf oil: } \beta \text {-caryophyllene }(\mathbf{1 9 1}, 16.6 \%) \text {, bicyclogermacrene }(\mathbf{1 9 7}, 14.1 \%), \beta \text {-pinene }(\mathbf{1 9 0}, 7.7 \%) \text {, } \\
\text { germacrene } \mathrm{D}(\mathbf{1 8 5}, 6.6 \%), \delta \text {-cadinene }(\mathbf{1 9 8}, 6.1 \%)[79]\end{array}$ \\
\hline B.pendula & $\begin{array}{l}\text { leaf oil: } \beta \text {-pinene }(\mathbf{1 9 0}, 10.4 \%), \beta \text {-caryophyllene }(\mathbf{1 9 1}, 8.6 \%), c(\mathbf{2 0 1}, 7.9 \%) \text { and } \\
\text { bicyclogermacrene }(\mathbf{1 9 7}, 7.2 \%)[80] \text {; branch oil: } \beta \text {-caryophyllene }(\mathbf{1 9 1}, 17.3 \%), \beta \text {-selinene }(\mathbf{2 0 2} \text {, } \\
\text { 9.1\%), bicyclogermacrene }(\mathbf{1 9 7}, 8.9 \%), \alpha \text {-cadinol }(\mathbf{2 0 0}, 5.8 \%) \text { and spathulenol }(\mathbf{2 0 3}, 4.6 \%)[80]\end{array}$ \\
\hline B. erythrophloia & $\begin{array}{l}\text { Leaf oil: } \beta \text {-caryophyllene }(\mathbf{1 9 1}, 22.6 \%), \alpha \text {-humulene }(\mathbf{2 0 4}, 21.9 \%) \text {, terpinen-4-ol }(\mathbf{2 0 5}, 5.3 \%) \text {, } \\
\text { cis- } \beta \text {-ocimene }(\mathbf{1 9 6}, 5.1 \%) \text {, sabinene }(\mathbf{2 0 6}, 5.0 \%) \text {, limonene }(\mathbf{2 0 7}, 4.5 \%)[81]\end{array}$ \\
\hline
\end{tabular}<smiles>C=C(/C=C/[C@H](CC/C(C)=C\CC(C)(C)C)C(C)C)CC</smiles><smiles>CC1=CC=C(C(C)C)CC1</smiles><smiles>CC(C)=CCCCC1CCCCC1</smiles><smiles>C=CC(CCCCC)OC(C)=O</smiles><smiles>C=CC(C)=CCC=C(C)C</smiles>

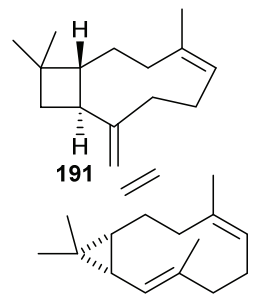

197<smiles>CCC(C)=O</smiles><smiles>CCC/C=C/C=O</smiles><smiles>C=CCCC1(C)CC=C(C)CC1</smiles><smiles>C=C(C)C</smiles><smiles>CCC/C=C\CO</smiles><smiles>C=C/C(C)=C(/C)CCC=C(C)C</smiles>
192

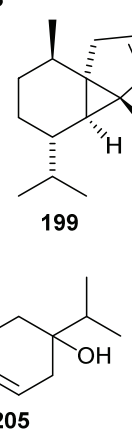
203<smiles>CC(C)C(C)C</smiles><smiles>CC1=CC2C(C)CC=C(C)C2CC1</smiles>

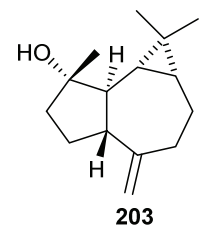<smiles>CC(C)=CCCC(C)=CCC(C)(C)C</smiles><smiles>C=C1CCC2(C(C)C)C3CC1C32C(C)C(C)C1(O)CC=C(C)CC1</smiles><smiles>CC1=CC23CCC(C(C)C)CC[C@H]2C(C)CCC3C1</smiles><smiles>CC1=CC2CCC1(C)C2(C)C</smiles><smiles>C=C(C)C(C)C1CCC2CCCC(=C)C2C1</smiles>

202<smiles>C=C(C)C1CC=C(C)CC1</smiles>

\subsection{Cyanoglycosides}

Chemotaxonomic studies indicated that terpenoids and alkaloids are common among plants of the Lauraceae family. In contrast, organic cyanides are very rare in Lauraceae and have only been reported from few species such as Cinnamomum camphora, Litsea glutinosa and Nectandra megaptamica. The investigation of 39 Australian Lauraceae species indicated that only B. collina was cyanogenic. 
In fact, from the methanol extract of $B$. collina, the first cyanogenic compound taxiphillin (208) was isolated from this genus [82].

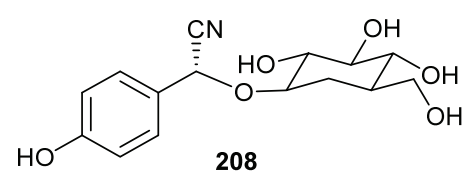

\subsection{Other Metabolites}

Steroids were isolated from extracts of many species from Beilschmiedia. Stigma-5-en-3-one (209), $\alpha$-tocospiro B (210), 33-hydroxystigma-5-en-7-one (211), stigmast-4-ene-3,6-dione (212), ergone (213), $\beta$-sitostenone (214), 6 $\alpha$-hydroxystigma-4-en-3-one (215) were isolated from the root of B. tsangii [25,26]. $\beta$-Sitosterol (216) was isolated from the stem of $B$. tsangii together with the pyrone derivatives

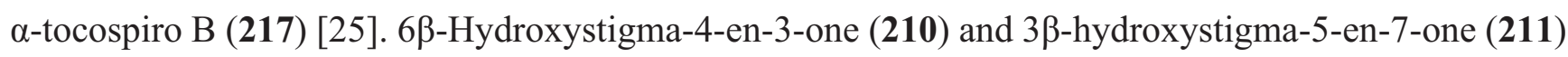
were also obtained from B. erythrophloia [41]. The fatty acid esters 2,3-dihydroxypropyl heptacosanoate (218), 1-(26-ferulyloxy hexacosanoyl)-glycerol (219) and 1-(26 hydroxyhexacosanoyl)-glycerol (220) were isolated from the stem of $B$. obscura together with $3 \beta$-acetylsitosterol (221) and $\beta$-sitosterol-3-O-Dglucopyranoside (222) [18]. $\beta$-Sitosterol (216) and $\beta$-sitosterol-3- $O$-D-glucopyranoside (222) were also isolated from B. zenkeri [18].

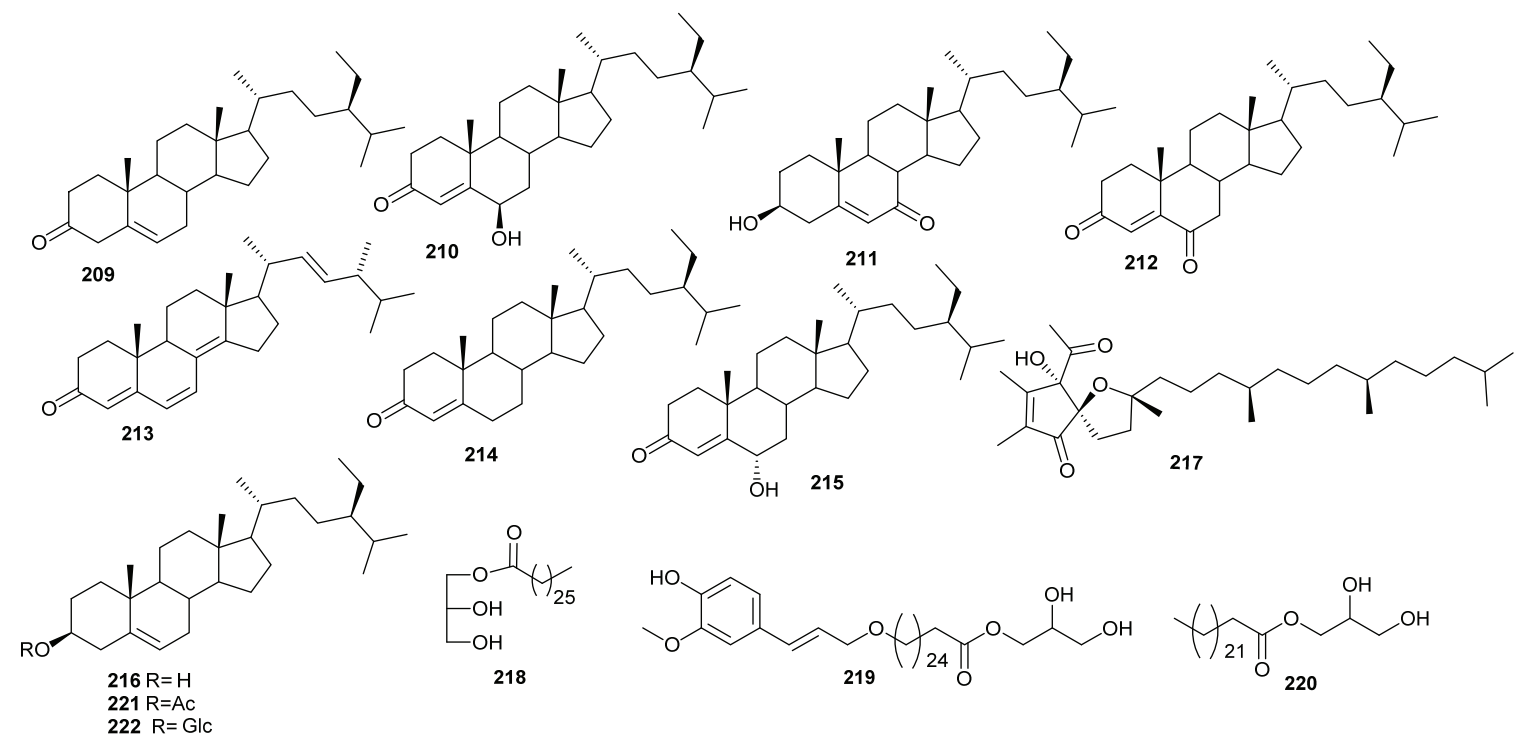

\section{Biological Activities}

Several interesting biological activities for the Beilschmiedia and Endiandra constituents have been reported, including antibacterial, anticancer, antifungal, antiinflammatory, antileishmanial, antiplasmodial and cytotoxic properties as well as $\alpha$-glucosidase inhibiting activity.

\subsection{Anticancer and Cytotoxic Activities}

Cancer cells that avoid apoptosis continue to proliferate uncontrollably. Apoptosis is an ordered and orchestrated cellular process that occurs in physiological and pathological conditions. An understanding of the underlying mechanism of apoptosis is important as it plays a pivotal role in the pathogenesis of 
many diseases. Degenerative diseases are characterized by too much apoptosis, while in the case of cancer, too little apoptosis occurs. Thus, resisting apoptosis is a key process in cancer development and progression [83]. Targeting the antiapoptotic proteins such as those of the Bcl-2 family members (Bcl-2, Bcl-xL, Bcl-w, Mcl-1, and A1) is essential for cancer treatment or preventive drug discovery. In addition, it has been shown that most cancers depend on more than one antiapoptotic Bcl-2 member for survival. The discovery of new selective inhibitors of antiapoptotic proteins is thus important for the search for anticancer drugs [84-87].

Endiandric acids derivatives isolated from Beilschmiedia and Endiandra species were screened for Bcl-xL and Mcl-1 binding affinities (Table 5). Amongst the tested compounds, ferrugineic acid B (38) exhibited the best binding affinity for Mcl-1 (85\% inhibition at $100 \mu \mathrm{M})$ while ferrugineic acid C (39) showed the highest binding affinity to Bcl-xL (93\% inhibition at $100 \mu \mathrm{M})$. Two compounds, ferrugineic acids B (38) and C (39), exhibited significant binding affinities for both antiapoptotic proteins. Apart from tsangibeilin $B$ (29) and ferrugineic acid J (46), the compounds that exhibited good binding affinity to Mcl-1 possess a $\mathrm{C}_{13}$ fused tetracyclic ring system with $\Delta^{4,5}$ and $\Delta^{8,9}$ double bonds. In the group of compounds with an $\mathrm{C}_{11}$ fused tetracylic ring system, only kingianic acid $\mathrm{C}(\mathbf{6 1})$ showed significant binding affinity to Mcl-1. No binding was detected from the compounds of this last fused tetracylic ring system for Bcl-xL. After the correlation between the structures and activities of compounds with $\mathrm{C}_{13}$ fused tetracyclic ring system, Appel and collaborators postulated that the length of the saturated carbon side chain, the $\beta$-oriented $\mathrm{C}-4$ hydroxy group and the terminal 4-hydroxyphenyl ring, play a crucial role for Bcl-xL and Mcl-1 binding affinities [24,34].

Table 5. Binding affinities of some endiandric acid derivatives to antiapoptotic proteins Bcl-xL and Mcl-1.

\begin{tabular}{|c|c|c|c|c|}
\hline \multirow{2}{*}{ Compound } & \multicolumn{2}{|c|}{ Bcl-xL/Bak Binding Affinity } & \multicolumn{2}{|c|}{ Mcl-1/Bid Binding Affinity } \\
\hline & $\%$ at $100 \mu \mathrm{M}$ & $\mathrm{K}_{\mathrm{i}} \mu \mathrm{M}$ & $\%$ at $100 \mu \mathrm{M}$ & $\mathrm{K}_{\mathrm{i}} \mu \mathrm{M}$ \\
\hline Tsangibeilin B (29) & $26 \pm 2.5$ & ND & $81 \pm 2.4$ & ND \\
\hline Ferrugineic acid A (37) & $22 \pm 2$ & $>100$ & 0 & $14 \pm 33$ \\
\hline Ferrugineic acid B (38) & $60 \pm 6$ & $19.2 \pm 1.6$ & $85 \pm 2$ & $12.0 \pm 5.0$ \\
\hline Ferrugineic acid C (39) & $93 \pm 3$ & $12 \pm 0.2$ & $82 \pm 2$ & $13.0 \pm 5.0$ \\
\hline Ferrugineic acid D (40) & $39 \pm 3$ & $>100$ & $82 \pm 2$ & $5.2 \pm 0.2$ \\
\hline Ferrugineic acid E (41) & $20 \pm 1$ & ND & $14.3 \pm 3$ & ND \\
\hline Ferrugineic acid F (42) & $7 \pm 1$ & ND & 0 & ND \\
\hline Ferrugineic acid $\mathrm{G}(\mathbf{4 3})$ & $17 \pm 1$ & ND & $3 \pm 1$ & ND \\
\hline Ferrugineic acid I (45) & $35 \pm 1$ & ND & $7 \pm 2$ & ND \\
\hline Ferrugineic acid J (46) & $58 \pm 7$ & $19.4 \pm 3$ & $81 \pm 3$ & $5.9 \pm 0.5$ \\
\hline Kingianic acid F (47) & $22 \pm 2.9$ & ND & $80 \pm 0.7$ & ND \\
\hline Kingianic acid G (48) & $19 \pm 1.6$ & ND & $47 \pm 2.9$ & ND \\
\hline Kingianic acid A (54) & $21 \pm 1.8$ & ND & $36 \pm 2.3$ & ND \\
\hline Endiandric acid M (56) & $10 \pm 0.5$ & ND & $39 \pm 2.9$ & ND \\
\hline Kingianic acid C (61) & $25 \pm 1.7$ & ND & $75 \pm 1.1$ & ND \\
\hline Kingianic acid E (63) & $1 \pm 0.8$ & ND & $8 \pm 5.5$ & ND \\
\hline U-Bak $\left(\mathrm{K}_{\mathrm{i}}\right)$ & & $0.0012 \pm 10^{-3}$ & & ND \\
\hline U-Bid $\left(\mathrm{K}_{\mathrm{i}}\right)$ & & & & $0.016 \pm 0.002$ \\
\hline $\operatorname{ABT}-737\left(\mathrm{~K}_{\mathrm{i}}\right)$ & $57 \pm 10 \mathrm{nM}$ & & $47 \pm 22 \mathrm{nM}$ & \\
\hline
\end{tabular}

NT: Not tested; U-Bak and U-bid correspond to unlabeled peptides Bak and Bid, respectively. 
The binding affinity of the racemic mixtures of kingianin A-N (112-125) isolated from E. kingiana was evaluated on Bcl-xL by competition against the fluorescently tagged $\mathrm{BH} 3$ domain of the protein Bak. Racemic mixtures of kingianins G-L (118-123) exhibited good binding affinity with kingianin G (118) exhibiting the best potency with a $\mathrm{K}_{\mathrm{i}}$ value of $2 \pm 0 \mu \mathrm{M}$ (Table 6). The pure enantiomers of these active racemates obtained using chiral preparative HPLC were evaluated for their binding affinity. Taking into account the stereochemistry of the compounds, the binding affinity was significantly higher for the (-)-enantiomers compared to the $(+)$-enantiomers, as illustrated by the comparison of the $\mathrm{K}_{\mathrm{i}}$ for $(-)$ and $(+)$-kingianin derivatives (Table 6) [43].

Table 6. Bcl-xL binding affinity of compounds 112-125 ( $\mathrm{K}_{\mathrm{i}}$ in $\left.\mu \mathrm{M}\right)$.

\begin{tabular}{cccc}
\hline \multirow{2}{*}{ Compound } & \multicolumn{3}{c}{ Bcl-xL $\mathbf{K}_{\mathbf{i}}$} \\
\cline { 2 - 4 } & Racemic mixture & $(-)$ Enantiomer & $(+)$ Enantiomer \\
\hline Kingianin A (112) & $213 \pm 83$ & $60 \pm 1.5$ & $>300$ \\
Kingianin B (113) & $>300$ & & \\
Kingianin C (114) & $>300$ & & \\
Kingianin D (115) & $>300$ & & \\
Kingianin E (116) & $>300$ & & \\
Kingianin F (117) & $231 \pm 47$ & $1.0 \pm 0.2$ & $27.0 \pm 1.0$ \\
Kingianin G (118) & $2 \pm 0$ & $4.0 \pm 0.4$ & $16.0 \pm 2.2$ \\
Kingianin H (119) & $18 \pm 7$ & $12.0 \pm 1.1$ & $71.0 \pm 4.0 \pm 10$ \\
Kingianin I (120) & $18 \pm 3$ & $9.0 \pm 0.2$ & \\
Kingianin J (121) & $29 \pm 6$ & $6.0 \pm 0.2$ & \\
Kingianin K (122) & $80 \pm 36$ & $4.0 \pm 0.1$ & \\
Kingianin L (123) & $36 \pm 11$ & & \\
Kingianin M (124) & $236 \pm 34$ & & \\
Kingianin N (125) & $177 \pm 9$ & & \\
Unlabeled Bak (BH3) & $0.90 \pm 0.27$ & & \\
\hline
\end{tabular}

Endiandric acid analogues isolated from unidentified Gabonese Beilschmiedia species were screened for their cytotoxicity against NCI-H460 (human lung cancer cell lines); PC-3 (prostate adenocarcinoma cell lines), and M14 (amelanotic melanoma cell lines) using an MTT assay. All the isolated compounds were inactive against PC-3, and M14 cell lines. Beilschmiedic acids K (17), L (19), M (18), N (20) and A (8) exhibited moderate cytotoxicity against NCI-H460 human lung cancer cells with IC50 values of 5.5; $5.9 ; 4.4 ; 8.7 ; 19 ; 6.1 \mu \mathrm{M}$, respectively. This was the first report of the cytotoxicity of this class of secondary metabolites [48]. Subsequently, other endiandric acid derivatives kingianic acids A (59), C (61), E (63), F (47), G (48), endiandric acid M (56), and tsangibeilin B (29) isolated from E. kingiana were evaluated for their cytotoxicity activity against A549 (lung adenocarcinoma epithelial cell lines), HT29 (colorectal adenocarcinoma cell lines) and PC3 cell lines. As reported by Williams et al. [48], all compounds were inactive against prostate adenocarcinoma cancer cell lines. Kingianic acid A (59) showed weak activity against HT-29 and A549 cell lines with $\mathrm{IC}_{50}$ values of $35 \pm 0.2 \mu \mathrm{M}$ and $85.4 \pm 0.2 \mu \mathrm{M}$, respectively. Kingianic acid E (63) showed moderate cytotoxic activity against A549 and HT-29 cell lines with $\mathrm{IC}_{50}$ values of $15.36 \pm 0.19 \mu \mathrm{M}$ and $17.10 \pm 0.11 \mu \mathrm{M}$, respectively [34]. The other tested compounds showed very weak or were devoid of cytotoxic activity against the cell lines tested. 
Ferrugineic acids A-J (37-46) and K (58), isolated from B. ferruginea, were screened for cytotoxicity against HCT-116 (Human colorectal carcinoma) and K562 (human leukemia) cancer cell lines. All these compounds were devoid of cytotoxicity on the two cancer cell lines tested at concentrations up to $50 \mu \mathrm{M}$ [24].

The cytotoxicity activities of lignans and other constituents of the stem of $B$. tsangii were evaluated in vitro against P-388 and HT-29 cell lines. Beilschmin A (133), B (134), C (135), tsangin A (137), B (138), 2,6,11-trimethyldodeca-2,6,10-triene (179), $\alpha$-tocopheryl quinone (167) and $\alpha$-tocospiro B (217) were cytotoxic ( $\mathrm{IC}_{50}$ below $4 \mu \mathrm{g} / \mathrm{mL}$ ) against the P-388 cell lines. Tsangin A (137), B (138) and $\alpha$-tocospiro B (217) were the most cytotoxic with $\mathrm{IC}_{50}$ values of $0.81 \pm 0.009,0.42 \pm 0.03$, and $0.83 \pm$ $0.09 \mu \mathrm{g} / \mathrm{mL}$, respectively, against the P-388 cell lines while 2,6,11-trimethyldodeca-2,6,10-triene (179) and $\alpha$-tocospiro B (217) exhibited the best potency against the HT-29 cell line amongst the isolated with $\mathrm{IC}_{50}$ values of $2.2 \pm 0.3$ and $1.5 \pm 0.2 \mu \mathrm{g} / \mathrm{mL}$, respectively [25].

Endiandrin A (143), endiandrin B (144), (-)-dihydroguaiaretic acid (145) isolated from E. anthropophagorum and the synthesized derivative cinbalansan (223) were also evaluated for their cytotoxicity against A549 cell line. In high-content screening (HCS) assays, (-)-dihydroguaiaretic acid (145) was found to be the most potent compound, displaying cytotoxicity against the A549 cell line with an $\mathrm{IC}_{50}$ of $7.49 \mu \mathrm{M}$ after $24 \mathrm{~h}$ incubation in both propidium iodide and Yo-PRO-1 assays. It effect was less pronounced in the mitotracker assay with $\mathrm{IC}_{50}$ of $31.2 \mu \mathrm{M}$. Endiandrin A (143), and B (144) were found to have moderate effects with an inhibition of $76 \%$ and $75 \%$ at $100 \mu \mathrm{M}$, respectively. Cinbalansan (223) was found to have much less effect with a maximum inhibition of 34\% [32].

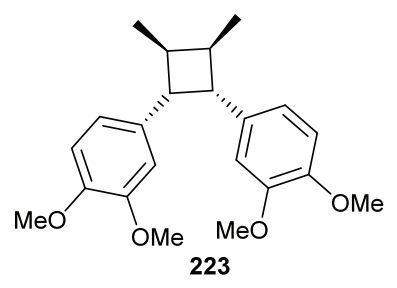

Alkaloids isolated from the leaves of B. brevipes exhibited cytotoxicity activity against P-388 murine leukemia cell lines. (6,7)-Dimethoxy-1-isoquinolinyl)-(4'-methoxyphenyl)methanone (94), $O, O$-dimethylcoclaurine (98), $O$-methylvelucryptine $(97),(R)$-(-)-armepavine (96) and $( \pm)$ - $N$-norarmepavine (95) were active with $\mathrm{IC}_{50}$ values of $18.7,6.5,17.3,42.2$ and 44.5, respectively [45].

The stem bark and leaf extracts of B. acuta were evaluated against a panel of human cancer cell lines, including various multidrug-resistant phenotypes. The leaf extracts showed $\mathrm{IC}_{50}$ values below or around $30 \mathrm{mg} / \mathrm{mL}$ in 10 cell lines. Interestingly, among them were multidrug-resistant cell lines, e.g., P-glycoprotein overexpressing CEM/ADR5000, breast cancer resistance protein-transfected MDA-MB-231-BCRP, TP53 knockout cells (HCT116 $553^{--}$), and mutation-activated epidermal growth factor receptor-transfected U87MG. $\triangle$ EGFR cells [88].

(-)-Kunstleramide (105) a dienamide from B. kunstleri displayed cytotoxic effect in MTT assays against A375 (melanoma cell lines), A549, HT-29, PC-3 and WRL-68 (normal liver) cell lines with $\mathrm{EC}_{50}$ values of $64.65,44.74,55.94,73.87$ and $70.95 \mu \mathrm{g} / \mathrm{mL}$, respectively [31]. Other amides $N$-trans-feryoloctopamine (110) and beilschamide (111) isolated from the stem of B. erythrophloia exhibited cytotoxic effects in vitro. They were active against CCRF-CEM (human lymphoblastic leukemia) cell line with $\mathrm{IC}_{50}$ values of 10.3 and $21.2 \mu \mathrm{g} / \mathrm{mL}$, respectively [69]. 
The essential oil obtained from the leaf of $B$. erythrophloia exhibited cytotoxic activity against human OEC-M1 (oral squamous cancer), J5 (hepatocellular carcinoma), A549, HT-29, UACC-62 (melanoma) and K562 (leukemic) cell lines. The results showed that treatment with the essential oil for $48 \mathrm{~h}$ reduced the viability of OEC-M1 cells, J5 cells, A549 cells, HT-29 cells, UACC-62 cells, and K562 cells, with $\mathrm{IC}_{50}$ around $32.6,48.6,38.8,18.9,5.8$, and $6.8 \mu \mathrm{g} / \mathrm{mL}$, respectively [77].

\subsection{Antimalaria Activity}

Malaria remains one of the most notorious infectious diseases in the world. It constitutes a public health problem in more than 90 countries, inhabited by about $40 \%$ of the world's population. The World Health Organisation estimates that there are 300-500 million malaria cases annually, causing 2-3 million deaths, mostly among children under five years old. In the last decades, resistance of Plasmodium falciparum, the causative agent of the most severe form of the disease, to several antimalarials, especially chloroquine and antifolates, became widely disseminated, while the cost of effective treatment is prohibitive for the large majority of the population in developing countries. For these reasons, new effective and affordable antimalarials are urgently needed [89-91]. In this perspective, extracts and some compounds isolated from Beilschmiedia species were screened for their antiplasmodial potency.

Cryptobeilic acids A-D (33-36) and tsangibeilin B (29) isolated from B. cryptocaryoides collected in Madagascar exhibited antiplasmodial activity in vitro against the chloroquine-sensitive strain of P. falciparum NF54 with IC50 values of $17.7,5.35,14.0,10.8$ and $8.2 \mu \mathrm{M}$, respectively. However, the cytotoxicity of these compounds against the L6 cell lines indicated low selectivity [52].

The antiplasmodial bioassay guided separation of the chemical constituents of the wood of the Indonesian medicinal plant $B$. madang led to the isolation of the bisbenzylisoquinoline dehatrine (100), that exhibited potent antiplasmodial activity against the chloroquine-resistant strain $P$. falciparum $\mathrm{k} 1$ with $\mathrm{IC}_{50}$ value of $0.17 \mu \mathrm{M}$, and which is comparable to that of the reference drug quinine against the same strain in vitro [12].

Pipyahyine (107), 5-hydroxy-7,8-dimethoxyflavanone (157), and betulinic acid (174) isolated from B. zenkeri exhibited antiplasmodial activity against the chloroquine-resistant strain of $P$. falciparum $\mathrm{W} 2$ with $\mathrm{IC}_{50}$ values of $3.7,9.3$ and $5.2 \mu \mathrm{M}$, respectively. Their activity were moderate compare to chloroquine (IC50 value of $0.13 \mu \mathrm{M}$ ), which was used as the positive control [18].

Lupeol (171), which showed in vitro inhibitory activity against the $P$. falciparum 3D7 strain with an IC 50 value of $27.7 \pm 0.5 \mu \mathrm{M}$, was shown to cause a transformation of the human erythrocyte shape toward that of stomatocytes [92].

\subsection{Anti-Asthmatic and Other Anti-Inflammatory Activities}

Asthma is a disease of the immune system, which is expressed for example as bronchial asthma in the form of acutely occurring, paroxysmal dyspnea with expiratory ventilation disability. Studies reported that persistent inflammation is central to the pathogenesis of asthma. So far, asthma therapy uses drugs which alleviate the symptoms but do not inhibit the mechanism responsible for the expression of inflammatory mediators such as the cytokines interleukin-4 (IL-4), interleukin-13 (IL-13) and interleukin-5 (IL-5) [93,94]. Endiandric acid H (7), obtained from the plant Beilschmiedia fulva, and its synthetic derivatives, known as c-maf, and NFAT inhibitors are used for producing a medicament, 
in particular for the treatment of allergic disorders, asthmatic disorders, inflammatory concomitant symptoms of asthma and/or of diseases which can be treated by inhibiting c-maf and NFAT [53,54].

The anti-inflammatory activities of extracts of $B$. tsangii have been studied. The methanol extract of the roots of $B$. tsangii showed potent inhibition of nitrogen monoxide (NO) production. Amongst the compounds isolated from this extract by bioassay guided separation, endiandric acid analogues endiandramide $\mathrm{A}$ (32) and B (57) with $N$-isobutylamide group exhibited potent iNOS inhibitory activities with $\mathrm{IC}_{50}$ values of 9.59 and $16.40 \mu \mathrm{M}$, respectively. Other isolates, tsangibeilin A (26), tsangibeilin B (29), endiandric acid K (54), endiandric acid M (56), endiandric acid L (55), and the lignans beilschminol A (128), beilschminol B (129), tsangin C (139) and tsangibeilin D (31), exhibited moderate anti-inflammatory activity with $\mathrm{IC}_{50}$ values in the range of 30-96 $\mu \mathrm{M}[22,23]$.

Synthetic glucocorticoids are widely used as drugs to treat inflammatory conditions such as rheumatoid arthritis or dermatitis and as adjunctive therapy for conditions such as autoimmune diseases. However, current glucocorticoid drugs act non-selectively, with the potential of long-term impairment of many physiological anabolic processes. Therefore, research aiming at the discovery of selective novel glucocorticoid receptor (GR) binders may provide new and improved drug therapies [95-98]. The bioguided fractionation of the dichloromethane extract of Endiandra anthropophagorum based on GR binding assay resulted in the isolation of the active lignans endiandin A (143), nectantin B (146) and (-)-dihydroguaiaretic acid (145) which displayed $\mathrm{IC}_{50}$ values of $0.9,27$ and $35 \mu \mathrm{M}$, respectively. The di-acetylated (224) and di-methylated (225) derivatives of endiandrin A also exhibited good activities with $\mathrm{IC}_{50}$ of 34 and $13 \mu \mathrm{M}$, respectively. From the structure-activity correlation, David and collaborators suggested that the constrained four-membered which has implications in the spatial arrangements of the substituents is important for the potent GR activity. In addition, increasing the steric bulk of the C-4/C-4' substituents in the cyclobutane series was shown to significantly reduce the activity [33].

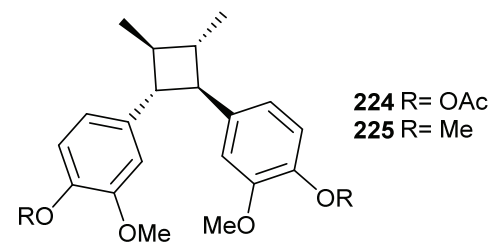

\subsection{Antimicrobial Activity}

Antibacterial activity of extracts and a number of endiandric acid derivatives and other constituents isolated from Beilschmiedia and Endiandra species have been studied.

Beilschmiedic acid A (8), B (9), and C (10), isolated from the stem bark of B. anacardioides, exhibited antibacterial activities against a wide range of microorganisms (Bacillus subtillis, Micrococcus luteus, Streptococcus faecalis) with minimum inhibitory concentrations (MICs) of 0.7-364 $\mu \mathrm{M}$. Compound 10 was found to be the most active derivative against the three tested strains with MICs of 5.6, 0.7 and $22.7 \mu \mathrm{M}$, respectively. Compounds 9 (MIC value of $11.3 \mu \mathrm{M}$ ) and 10 (MIC value of $5.6 \mu \mathrm{M}$ ) were found to be more active than the reference drug ampicillin (MIC value of $89.5 \mu \mathrm{M}$ ) against $B$. subtillis. Compound 10 was also more active than the reference drug ampicillin (MIC value of $5.58 \mu \mathrm{M}$ ) against M. luteus [17]. 
Compound $\mathbf{8}$ and other endiandric acid derivatives beilschmiedic acids $\mathrm{I}-\mathrm{O}$ (15-21), isolated from an unidentified Gabonese Beilschmiedia species, exhibited potent antibacterial activity against a clinical isolate of methicillin-resistant $S$. aureus (MRSA) with MIC values between 10 and $13 \mu \mathrm{g} / \mathrm{mL}$ [48].

Cryptobeilic acids A (33) and B (34) isolated from B. cryptocaryoides displayed antibacterial activity against Escherichia coli $6 \mathrm{r} 3$ with MIC values of 10 and $20 \mu \mathrm{g} / \mathrm{mL}$, respectively. Their activity were moderate compared to that of the reference drug ampicillin (MIC value of $5 \mu \mathrm{g} / \mathrm{mL}$ ) [52].

Endiandric acid erythrophloin C (24) with phenyl in the side chain isolated from B. erythrophloia exhibited antitubercular activity against Mycobacterium tuberculosis with MIC of $50 \mu \mathrm{g} / \mathrm{mL}$ [41].

In addition to endiandric acid derivatives, other constituents of Beilschmiedia and Endiandra genera have also exhibited antibacterial activity in vitro against some strains of bacteria. The amide pipyahyine (107) and beilschmieflavonoid B (156) isolated from the stem of B. zenkeri exhibited antibacterial activity in vitro against Bacillus subtilis, $P$. agarici and S. minor with MICs between 81.5-197.5 $\mu \mathrm{M}[18]$.

Magnolol (141), a neolignan isolated from different Endiandra species, showed strong antibacterial activities against both Propionibacterium acnes and Propionibacterium granulosum, which are acne-causing bacteria with the MIC value of $9 \mu \mathrm{g} / \mathrm{mL}$ [99].

Beilschmin A (133) and B (134), two lignans isolated from B. tsangii, exhibited potent antitubercular activities with MICs of 2.5 and $7.5 \mu \mathrm{g} / \mathrm{mL}$, respectively. These compounds were more active than

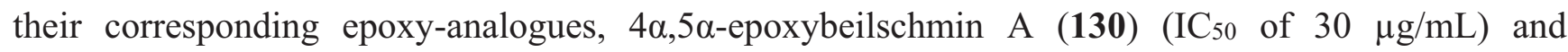
$4 \alpha, 5 \alpha$-epoxybeilschmin B (131 ( $\mathrm{IC}_{50}$ of $\left.40 \mu \mathrm{g} / \mathrm{mL}\right)$. As reported by Chen et al. [48], the epoxidation of the $\mathrm{C} 4 / \mathrm{C} 5$ bond of compounds $\mathbf{1 3 3}$ and $\mathbf{1 3 4}$ considerably reduce their antibacterial activity against M. tuberculosis. Beilschmin A (133) with MICs of $2.5 \mu \mathrm{g} / \mathrm{mL}$ was most active than the reference compound, ethambutol (MIC of $6.2 \mu \mathrm{g} / \mathrm{mL}$ ) [26]. The sesquiterpene suberosol B (180) isolated from B. erythrophloia also exhibited potent antitubercular activity against M. tuberculosis $\mathrm{H} 37 \mathrm{Rv}$ in vitro with MIC of $28.9 \mu \mathrm{g} / \mathrm{mL}$ [41].

The methanol extract of the wood of $B$. tovarensis showed significant antibacterial activity results against Staphylococcus aureus and Enterococcus faecalis [13]. The methanol extract of the fruits of B. obscura showed antibacterial activity against multi-resistant drugs strains of Escherichia coli, Enterobacter aerogenes, Klebsiella pneumoniae, Enterobacter cloacae, Pseudomonas aeruginosa, and Providencia stuartii with MICs between 16-128 $\mu \mathrm{g} / \mathrm{mL}[100]$.

Essential oils from the leaves and bark of $B$. madang showed moderate antibacterial activity towards B. subtilis and S. aureus with identical minimum inhibitory concentrations (MIC), $125 \mu \mathrm{g} / \mathrm{mL}$. They also exhibited activity towards E. faecalis with MIC value of $250 \mu \mathrm{g} / \mathrm{mL}$. Both oils were also found to be active against Gram-negative bacteria, K. pneumoniae with MIC value of $250 \mu \mathrm{g} / \mathrm{mL}$ [77].

The antifungal activities of extracts and the isolates from Beilschmiedia and Endiandra were also reported. The essential oils from the bark of $B$. madang showed strong antifungal activity towards Aspergillus niger and A. fumigatus with identical MIC values, $62.5 \mu \mathrm{g} / \mathrm{mL}$ [78].

The crude methanolic extract of B. alloiophylla was found to be active against Candida albicans in vitro. Alkaloids isolated from this extract boldine (74), 2-hydroxy-9-methoxyaporphine (81), laurotetanine (82), secoboldine $(\mathbf{8 9})$, isoboldine $(\mathbf{8 0})$, asimilobine $(\mathbf{8 3})$, oreobeiline $(\mathbf{8 7})$, 6-epioreobeiline $(\mathbf{8 8})$, liriodenine (90), $(S)$-3-methoxynordomesticine (91) and the triterpenoid $\beta$-amyrone (174) exhibited good antifungal activity against the same strain with MICs in the range of $8-64 \mu \mathrm{g} / \mathrm{mL}$ [29]. Paulo and 
collaborators reported moderate antifungal activity for laurelliptine (79) and isoboldine (80) in vitro against Tricophyton rubrum and Microsporum gypseun [101].

\subsection{Other Activities}

Essential oil from the leaves of Beilschmiedia madang exhibited cholinesterase and tyrosinase inhibiting activities in vitro with inhibition of $55.2 \%, 60.4 \%$, and $53.1 \%$ for acetyl-, butyrylcholinesterase and tyrosinase at $1000 \mu \mathrm{g} / \mathrm{mL}$, respectively [78]. The crude methanolic extract of B. alloiophylla inhibited acetylcholinesterase and $\alpha$-glucosidase in vitro. Four compounds from this extract, oreobeiline (87), 6-epioreobeiline (88), $\beta$-amyrone (174), and $(S)$-3-methoxynordomesticine (91), displayed moderate inhibitory activity against $\alpha$-glucosidase with $\mathrm{IC}_{50}$ values of $8.0,10.0,20.0$, and $10.0 \mu \mathrm{M}$, respectively. Other isolates from the same extract, 2-hydroxy-9-methoxyaporphine (81), laurotetanine (82) and liriodenine (90), displayed strong inhibitory activity against AchE with $\mathrm{IC}_{50}$ values of 2.0, 3.2 and $3.5 \mu \mathrm{M}$, comparable to that of the reference substance huperzine ( $\mathrm{IC}_{50}$ values of $1.8 \mu \mathrm{M}$ ) [29].

The essential oils from the leaves of $B$. tilaranensis and B. brenesii exhibited enzyme inhibitory activities against cruzain, a potential therapeutic target for Chagas' disease, a parasitic disease caused by Trypanosoma cruzi and that occurs mostly in South and Central American countries, with IC50 values of $23.6 \mu \mathrm{g} / \mathrm{mL}$ and $61.9 \mu \mathrm{g} / \mathrm{mL}$, respectively [102-104].

The crude methanolic extract of B. alloiophylla was shown to exhibit antileishmanial activity in vitro. Compounds isolated from this extract, 2-hydroxy-9-methoxyaporphine (81), laurotetanine (82), liriodenine (91), boldine (74), secoboldine (90), isoboldine (80), asimilobine (83), oreobeiline (87), 6-epioreobeiline (88), $\beta$-amyrone (174), and $(S)$-3-methoxynordomesticine (91) exhibited moderate activity with $\mathrm{IC}_{50}$ values in the range of $10-50 \mu \mathrm{M}$ [29].

The essential oils from B. madang exhibited weak DPPH radical scavenging activity (IC50 leaf oil, $263.9 \mu \mathrm{g} / \mathrm{mL}$; bark oil, $212.0 \mu \mathrm{g} / \mathrm{mL}$ ) compared to standard antioxidant, butylated hydroxytoluene (IC50 of $18.5 \mu \mathrm{g} / \mathrm{mL}$ ) [78]. (-)-Kunstleramide (105) an dienamide from B. kunstleri exhibited very poor dose-dependent inhibition of DPPH (2,2-diphenyl-1-picrylhydrazyl) activity, with an IC50 value of $179.5 \pm 4.4 \mu \mathrm{g} / \mathrm{mL}$ [31].

\section{Conclusions}

The genera Beilschmiedia and Endiandra include ca. 250 and ca. 125 species, respectively. Only 31 species of Beilschmiedia and 11 species of Endiandra have been investigated phytochemically, indicating that there are still many species that have received little or no attention. Secondary metabolites isolated from the two genera, can be classified as endiandric acid derivatives (30.9\%), alkaloids and amides (23.7\%), lignans and neolignans (9.5\%), flavonoids and chalcones (5.8\%) and others (30.21\%: terpenoids, benzene derivatives, steroids, cyanoglycoside, fatty acids). Although being the majority of the isolates, the endiandric acid derivatives were not isolated from all species of Beilschmiedia or Endiandra investigated. This class of compounds and alkaloids is more widespread and the investigation of the remaining species could led to new derivatives. Bioassay on extracts and secondary metabolites of these species revealed pronounced biological properties, such as Bcl-xL and Mcl-1 binding affinity, $\alpha$-glucosidase inhibiting activity, antimicrobial, anti-inflammatory, antiplasmodial, and cytotoxic properties. In addition to these bioactive secondary metabolites, essential oils from these species displayed 
good biological activities against a wide range of microorganisms and also enzyme inhibitory properties. The structural diversity of Beilschmiedia and Endiandra constituents and their interesting biological activities indicate that they are two potential sources of other new drugs such as that used in the treatment of asthma.

\section{Acknowledgments}

The authors wish to acknowledge the Alexander von Humboldt Foundation for providing a fellowship to Bruno Lenta Ndjakou at Bielefeld University.

\section{Author Contributions}

All authors designed and wrote the review. They contributed interactively to explore the background literature and to the writing procedure.

\section{Conflicts of Interest}

The authors declare no conflict of interest.

\section{References}

1. Nishida, S. Revision of Beilschmiedia (Lauraceae) in the neotropics. Ann. Mo. Bot. Gard. 1999, $86,657-701$.

2. Liao, J.-C. Lauraceae: Flora of Taiwan, 2nd ed.; Editorial Committee of the Flora of Taiwan: Taipei, Taiwan, 1996; Volume 2, pp. 433-499.

3. Ng, F.S.P. Tree Flora of Malaya; Longman: Kuala Lumpur, Malaysia, 1989; p. 4.

4. Henry, T.A. The Plant Alkaloids, 4th ed.; J.A. Churchill Ltd.: London, UK, 1949; p. 317.

5. Perry, L.M.; Metzgr, J. Medicinal Plants East and Southest Asia: Attributed Properties and Uses; MIT Press: Cambridge, MA, USA, 1980; Volume 20, pp. 201-202.

6. Fouilloy, R. Flore du Cameroun (Lauracées, Myristicaées et Momimiacées); Muséum National d'Histoire Naturelle: Paris, France, 1974; Volume 18, p. 8.

7. Van der Werff, H. A synopsis of the genus Beilschmiedia (Lauraceae) in Madagascar. Adansonia 2003, 3, 77-92.

8. Nkeng-Efouet, A.P. Phytochemicals from Beilschmiedia Anacardioides and Their Biological Significance: Phytochemicals-A Global Perspective of Their Role in Nutrition and Health; Rao, V., Ed.; InTech: Rijeka, Croatia, 2012; pp. 167-186.

9. Burkill, I.H. A Dictionary of the Economic Products of the Malay Peninsular, 2nd ed.; Government of Malaya and Singapore: Kuala Lumpur, Malaysia, 1966; p. 1773.

10. Maberley, D.J. Mabberley's Plant-Book: A Portable Dictionary of Plants, Their Classification and Uses, 3rd ed.; Cambridge University Press: Cambridge, UK, 2008; p. 1021.

11. Maberley, D.J. The plant-book: A Portable Dictionary of the Vascular Plants, 2nd ed.; Cambridge University Press: Cambridge, UK, 1997; p. 858. 
12. Kitagawa, I.; Minagawa, K.; Zhang, R.S.; Hori, K.; Doi, M.; Inoue, M.I.; Ishida, T.; Kimura, M.; Uji, T.; Shibuya, H. Dehatrine, an antimalarial bisbenzylisoquinoline alkaloid from the Indonesian medicinal plant Beilschmiedia madang, isolated as a mixture of two rotational isomers. Chem. Pharm. Bull. 1993, 41, 997-999.

13. Suarez, L.E.C.; Vargas, O.E.B. New chalcones from Beilschmiedia tovarensis. Rev. Colomb. Quim. 2005, 34, 35-41.

14. Iwu, M.M. Handbook of African Medicinal Plants; CRC Press: BocaRaton, FL, USA, 1993; p. 435.

15. Tchiegang, C.; Parmentier, M. Chemical composition and nutritional evaluation of two Cameroonian soup thickeners: Belschmiedia jacques felexii and Belschmiedia anacardiodes. J. Food Sci. Tech. 2008, 45, 187-189.

16. Sahoré, A.D.; Koffi, L.B. Technical sheet of Beisclmiedia mannii (Lauraceae) seed preparation in Ivory Coast. J. Pharm. Sci. Innov. 2013, 2, 62-64.

17. Chouna, J.R.; Nkeng-Efouet, P.A.; Lenta, B.N.; Devkota, K.P.; Neumann, B.; Stammler, H.G.; Kimbu, S.F.; Sewald, N. Antibacterial endiandric acid derivatives from Beilschmiedia anacardioides. Phytochemistry 2009, 70, 684-688.

18. Lenta, B.N.; Tantangmo, F.; Devkota, K.P.; Wansi, J.D.; Chouna, J.R.; Soh, R.C.F.; Neumann, B.; Stammler, H.-G.; Tsamo, E.; Sewald, N. Bioactive constituents of the stem bark of Beilschmiedia zenkeri. J. Nat. Prod. 2009, 72, 2130-2134.

19. Chouna, J.R.; Nkeng-Efouet, P.A.; Lenta, B.N.; Wansi, D.J.; Neumann, B.; Stammler, H.-G.; Fon Kimbu, S.; Sewald, N. Beilschmiedic acids F and G, other endiandric Acid derivatives from Beilschmiedia anacardioides. Helv. Chim. Acta 2011, 94, 1071-1076.

20. Chouna, J.R.; Nkeng-Efouet, P.A.; Lenta, B.N.; Wansi, J.D.; Fon Kimbu, S.; Sewald, N. Endiandric acid derivatives from the stem bark of Beilschmiedia anacardioides. Phytochem. Lett. 2010, 3, 13-16.

21. Harborne, J.B.; Mendez, J. Flavonoids of Beilschmiedia miersii. Phytochemistry 1969, 8, 763-764.

22. Huang, Y.-T.; Chang, H.-S.; Wang, G.-J.; Lin, C.-H.; Chen, I.-S. Secondary metabolites from the roots of Beilschmiedia tsangii and their anti-inflammatory activities. Int. J. Mol. Sci. 2012, 13, 16430-16443.

23. Huang, Y.-T.; Chang, H.-S.; Wang, G.-J.; Cheng, M.-J.; Chen, C.-H.; Yang, Y.-J.; Chen, I.-S. Anti-inflammatory endiandric acid analogues from the roots of Beilschmiedia tsangii. J. Nat. Prod. 2011, 74, 1875-1880.

24. Apel, C.; Geny, C.; Dumontet, V.; Birlirakis, N.; Roussi, F.; Pham, V.C.; Huong, D.T.M.; Nguyen, V.H.; Chau, V.M.; Litaudon, M. Endiandric acid analogues from Beilschmiedia ferruginea as dual inhibitors of Bcl-xL/Bak and Mcl-1/Bid interactions. J. Nat. Prod. 2014, 77, 1430-1437.

25. Chen, J.-J.; Chou, E.-T.; Duh, C.-Y.; Yang, S.-Z.; Chen, I.-S. New cytotoxic tetrahydrofuran- and dihydrofuran-type lignans from the stem of Beilschmiedia tsangii. Planta Med. 2006, 72, 351-357.

26. Chen, J.-J.; Chou, E.-T.; Peng, C.-F.; Chen, I.-S.; Yang, S.-Z.; Huang, H.-Y. Novel epoxyfuranoid lignans and antitubercular constituents from the leaves of Beilschmiedia tsangii. Planta Med. 2007, 73, 567-571.

27. Kumamoto, J.; Scora, R.W. Structure of sarisan, an isomer of myristicin, isolated from the leaf oil of Beilschmiedia miersii. J. Agric. Food Chem. 1970, 18, 544-545. 
28. Lenta, B.N.; Chouna, J.R.; Nkeng-Efouet, P.A.; Fon Kimbu, S.; Tsamo, E.; Sewald, N. Obscurine: A new cyclostachine acid derivative from Beilschmiedia obscura. Nat. Prod. Commun. 2011, 6, 1591-1592.

29. Mollataghi, A.; Coudiere, E.; Hadi, A.H.A.; Mukhtar, M.R.; Awang, K.; Litaudon, M.; Ata, A. Anti-acetylcholinesterase, anti- $\alpha$-glucosidase, anti-leishmanial and anti-fungal activities of chemical constituents of Beilschmiedia species. Fitoterapia 2012, 83, 298-302.

30. Mollataghi, A.; Hadi, A.H.A.; Awang, K.; Mohamad, J.; Litaudon, M.; Mukhtar, M.R. $(+)-K u n s t l e r o n e$, a new antioxidant neolignan from the leaves of Beilschmiedia kunstleri Gamble. Molecules 2011, 16, 6582-6590.

31. Mollataghi, A.; Hadi, A.H.; Cheah, S.-C. (-)-Kunstleramide, a new antioxidant and cytotoxic dienamide from the bark of Beilschmiedia kunstleri Gamble. Molecules 2012, 17, 4197-4208.

32. Davis, R.A.; Barnes, E.C.; Longden, J.; Avery, V.M.; Healy, P.C. Isolation, structure elucidation and cytotoxic evaluation of endiandrin B from the Australian rain forest plant Endiandra anthropophagorum. Bioorg. Med. Chem. 2009, 17, 1387-1392.

33. Davis, R.A.; Carroll, A.R.; Duffy, S.; Avery, V.M.; Guymer, G.P.; Forster, P.I.; Quinn, R.J. Endiandrin A, a potent glucocorticoid receptor binder isolated from the Australian plant Endiandra anthropophagorum. J. Nat. prod. 2007, 70, 1118-1121.

34. Azmi, M.N.; Geny, C.; Leverrier, A.; Litaudon, M.; Dumontet, V.; Birlirakis, N.; Gueritte, F.; Leong, K.H.; Abd, H.; Siti, N.; et al. Kingianic acids A-G, endiandric acid analogues from Endiandra kingiana. Molecules 2014, 19, 1732-1747.

35. Bandaranayake, W.M.; Banfield, J.E.; Black, D.S.C.; Fallon, G.D.; Gatehouse, B.M. Endiandric acid, a novel carboxylic acid from Endiandra introrsa (Lauraceae): X-ray structure determination. J. Chem. Soc. Chem. Comm. 1980, 4, 162-163.

36. Bandaranayake, W.M.; Banfield, J.E.; Black, D.S.C.; Fallon, G.D.; Gatehouse, B.M. Constituents of Endiandra species. I. Endiandric acid, a novel carboxylic acid from Endiandra introrsa (Lauraceae), and a derived lactone. Aust. J. Chem. 1981, 34, 1655-1667.

37. Bandaranayake, W.M.; Banfield, J.E.; Black, D.S.C. Constituents of Endiandra species. II. (E)-4-(6'phenyltetracyclo[5.4.2.03,13.010,12]trideca-4',8'-dien-11'-yl)but-2-enoic acid from Endiandra introsa (Lauraceae). Aust. J. Chem. 1982, 35, 557-565.

38. Bandaranayake, W.M.; Banfield, J.E.; Black, D.S.C.; Fallon, G.D.; Gatehouse, B.M. Constituents of Endiandra species. III. 4-[(E,E)-5'-Phenylpenta-2',4'-dien-1'-yl]tetracyclo[5.4.0.02.5.03.9]undec-10ene-8-carboxylic acid from Endiandra introrsa (Lauraceae). Aust. J. Chem 1982, 35, 567-579.

39. Banfield, J.E.; Black, D.S.C.; Johns, S.R.; Willing, R.I. Constituents of Endiandra species. IV. Isolation of 2-(8'-[(E,E)-5"-phenylpenta-2",4"-dien-1"-yl]bicyclo[4.2.0]octa-2',4'-dien-7'-yl)acetic acid, a biogenetically predicted metabolite of Endiandra introrsa (Lauraceae) and its structure determination by means of 1D and 2D NMR spectroscopy. Aust. J. Chem. 1982, 35, 2247-2256.

40. Banfield, J.E.; Black, D.S.C.; Collins, D.J.; Hyland, B.P.M.; Lee, J.J.; Pranowo, S.R. Constituents of some species of Beilschmiedia and Endiandra (Lauraceae): New endiandric acid and benzopyran derivatives isolated from B. oligandra. Aust. J. Chem. 1994, 47, 587-607.

41. Yang, P.-S.; Cheng, M.-J.; Peng, C.-F.; Chen, J.-J.; Chen, I.-S. Endiandric acid analogues from the roots of Beilschmiedia erythrophloia. J. Nat. Prod. 2009, 72, 53-58. 
42. Leverrier, A.; Dau, M.E.T.H.; Retailleau, P.; Awang, K.; Gueritte, F.; Litaudon, M. Kingianin A: A new natural pentacyclic compound from Endiandra Kingiana. Org. Lett. 2010, 12, 3638-3641.

43. Leverrier, A.; Awang, K.; Gueritte, F.; Litaudon, M. Pentacyclic polyketides from Endiandra kingiana as inhibitors of the Bcl-xL/Bak interaction. Phytochemistry 2011, 72, 1443-1452.

44. Mpetga, S.D.J. Contribution à L'étude Phytochimique D'une Plante Médicinale du Cameroun: Beilschmiedia mannii (Lauracee). Ph.D. Thesis, Université de Dschang, Dschang, Cameroon, 2005.

45. Pudjiastuti, P.; Mukhtar, M.R.; Hadi, A.H.A.; Saidi, N.; Morita, H.; Litaudon, M.; Awang, K. 6,7-Dimethoxy-4-methylisoquinolinyl)-(4'-methoxyphenyl)-methanone, a new benzylisoquinoline alkaloid from Beilschmiedia brevipes. Molecules 2010, 15, 2339-2346.

46. Russell, G.B.; Fraser, J.G. Identification of isoboldine as the major alkaloid form berries of Beilschmiedia tawa. New Zeal. J. Sci. 1969, 12, 694-695.

47. Tillequin, F.; Koch, M.; Pusset, J.; Chauviere, G. Two new morphinane alkaloids from Beilschmiedia oreophila Schlechter (Lauraceae). Heterocycles 1985, 23, 1357-1361.

48. Williams, R.B.; Martin, S.M.; Hu, J.-F.; Norman, V.L.; Goering, M.G.; Loss, S.; O’Neil-Johnson, M.; Eldridge, G.R.; Starks, C.M. Cytotoxic and antibacterial beilschmiedic acids from a Gabonese species of Beilschmiedia. J. Nat. Prod. 2012, 75, 1319-1325.

49. Yang, P.-S.; Cheng, M.-J.; Chen, J.-J.; Chen, I.-S. Two new endiandric acid analogs, a new benzopyran, and a new benzenoid from the root of Beilschmiedia erythrophloia. Helv. Chim. Acta 2008, 91, 2130-2138.

50. Zhang, J.; Ma, Z.; Feng, J.; Feng, G.; Zhang, X. Bioactivity of sarisan against Musca domestica L. and Culex pipiens pallens. J. Chin. J. Pest. Sci. 2005, 71, 85-87.

51. Li, Y.; Jiang, G.; Wang, H. On analysis of bactericidal ability and effective component of four garden trees. J. Southwest. China Norm. Univ. Nat. Sci. 2014, 39, $29-34$.

52. Talontsi, F.M.; Lamshöft, M.; Bauer, J.O.; Razakarivony, A.A.; Andriamihaja, B.; Strohmann, C.; Spiteller, M. Antibacterial and antiplasmodial constituents of Beilschmiedia cryptocaryoides. J. Nat. Prod. 2013, 76, 97-102.

53. Eder, C.; Kogler, H.; Haag-Richter, S. New Fused Tetracyclic Compounds, e.g., Endiandric Acid H Obtained from the Plant Beilschmieda fulva, are C-maf and NFAT Inhibitors Useful for Treating Allergy or Asthma. German Patent DE 10235624 A1, 19 February 2004.

54. Eder, C.; Kogler, H.; Haag-Richter, S. Endiandric Acid H and Its Derivatives, Process for Their Preparation and Use Thereof. U.S. Patent US007019028B2, 28 March 2006.

55. Nicolaou, K.C.; Petasis, N.A.; Zipkin, R.E.; Uenishi, J. The endiandric acid cascade. Electrocyclizations in organic synthesis. 1 stepwise, stereocontrolled total synthesis of endiandric acids A and B. J. Am. Chem. Soc. 1982, 104, 5555-5557.

56. Reynolds, W.F.; Enriquez, R.G. Choosing the best pulse sequences, acquisition parameters, postacquisition processing strategies, and probes for natural product structure elucidation by NMR spectroscopy. J. Nat. Prod. 2002, 65, 221-244.

57. Bross-Walch, N.; Kühn, T.; Moskau, D.; Zerb, O. Strategies and tools for structure determination of natural products using modern methods of NMR spectroscopy. Chem. Biodivers. 2005, 2, 147-177.

58. Coy Barrera, E.D.; Cuca Suárez, L.E. In vitro inhibitory activities of Lauraceae aporphine alkaloids. Nat. Prod. Commun. 2010, 5, 383-386. 
59. Omar, H.; Hashim, N.M.; Zajmi, A.; Nordin, N.; Abdelwahab, S.I.; Azizan, A.H.S.; Hadi, A.H.A.; Ali, H.M. Aporphine alkaloids from the leaves of Phoebe grandis (Nees) Mer. (Lauraceae) and their cytotoxic and antibacterial activities. Molecules 2013, 18, 8994-9009.

60. Nasrullah, A.A.; Zahari, A.; Mohamad, J.; Awang, K. Antiplasmodial alkaloids from the bark of Cryptocarya nigra (Lauraceae). Molecules 2013, 18, 8009-8017.

61. Stermitz, F.R.; Castro, O.C. Pentasubstituted aporphine alkaloids from Phoebe molicella. J. Nat. Prod. 1983, 46, 913-916.

62. Custódio, D.L.; da Veiga, J.V.F. Lauraceae alkaloids. RSC Adv. 2014, 4, 21864-21890.

63. Pabon, L.C.; Cuca, L.E. Aporphine alkaloids from Ocotea macrophylla (Lauraceae). Quim Nova 2010, 33, 875-879.

64. Chen, J.; Gao, K.; Liu, T.; Zhao, H.; Wang, J.; Wu, H.; Liu, B.; Wang, W. Aporphine alkaloids: A kind of alkaloids' extract source, chemical constitution and pharmacological actions in different botany. Asian J. Chem. 2013, 25, 10015-10027.

65. Tschesche, R.; Welzel, P.; Legler, G. Structure of certain tetrasubstituted aporphine alkaloids. Tetrahedron Lett. 1965, 8, 445-450.

66. Johns, S.R.; Lamberton, J.A.; Sioumis, A.A.; Tweeddale, H.J. New aporphine alkaloids from Beilschmiedia podagrica. Aust. J. Chem. 1969, 22, 1277-1281.

67. Clezy, P.S.; Gellert, E.; Lau, D.Y.K.; Nichol, A.W. The alkaloids of Beilschmiedia elliptica. Aust. J. Chem. 1966, 19, 135-142.

68. Clezy, P.S.; Nichol, A.W.; Gellert, E. Structures of laurelliptine, a new aporphine alkaloid, and thalicmidine. Experientia 1968, 19, 1-2.

69. Chen, J.-J.; Kuo, W.-L.; Sung, P.-J.; Chen, I.-S.; Cheng, M.-J.; Lim, Y.-P.; Liao, H.-R.; Chang, T.-H.; Wei, D.-C.; Chen, J.-Y. Beilschamide, a new amide, and cytotoxic constituents of Beilschmiedia erythrophloia. Chem. Nat. Compd. 2015, 51, 302-305.

70. Monte Neto, R.L.; Sousa, L.M.; Dias, C.S.; Filho, J.M.; Oliveira, M.R. Yangambin cytotoxicity: A pharmacologically active lignan obtained from Ocotea duckei Vattimo (Lauraceae). Z. Naturforsch C. 2008, 63, 681-686.

71. Filho da Silva, A.A.; Costa, E.S.; Cunha, W.R.; Silva, M.L.A.; Nanayakkara, N.P.D.; Bastos,J.K. In vitro antileishmanial and antimalarial activities of tetrahydrofuran lignans isolated from Nectandra megapotamica (Lauraceae). Phytother. Res. 2008, 22, 1307-1310.

72. Yang, L.J.; Chen, W.; Luo, Y.P.; Li, G.P.; Yang, X.D.; Li, L. Lignans and ketonic compounds from Litsea chinpingensis (Lauraceae). Biochem. Syst. Ecol. 2009, 37, 696-698.

73. Yang, J.Y. A Flavonoid Study of the Lauraceae. Master Thesis, The University of British Columbia, Vancouver, Canada, 1998.

74. Gomez-Garibay, F.; Calderon, J.S.; Quijano, L.; Tallez, O.; Olivares, M.D.S.; Rios, T. An unusual prenyl biflavanol from Tephrosia tepicana. Phytochemistry 1997, 46, 1285-1287.

75. Scora, R.W.; Scora, P.E. Essential leaf oil of Persea subgenus, Eriodaphne and closely related Perseoid genera. J. Essent. Oil Res. 2001, 13, 37-42.

76. Agius, B.R.; Setzer, M.C.; Stokes, S.L.; Walker, T.M.; Haber, W.A.; Setzer, W.N. Composition and bioactivity of essential oils of Lauraceae from Monteverde, Costa Rica. Int. J. Essent. Oil Ther. 2007, 1, 167-171. 
77. Setzer, W.N.; Haber, W.A. Leaf essential oil composition of five species of Beilschmiedia from Monteverde, Costa Rica. Nat. Prod. Commun. 2007, 2, 79-83.

78. Salleh, W.M.; Ahmad, F.; Yen, K.H. Chemical compositions and biological activities of the essential oils of Beilschmiedia madang Blume (Lauraceae). Arch. Pharm. Res. 2014, 38, 485-493.

79. Wright, B.S.; Bansal, A.; Moriarity, D.M.; Takaku, S.; Setzer, W.N. Cytotoxic leaf essential oils from neotropical Lauraceae: Synergistic effects of essential oil components. Nat. Prod. Commun. 2007, 2, 1241-1244.

80. Chaverri, C.; Ciccio, J.F. Essential oils from Beilschmiedia pendula (Sw.) Hemsl. (Lauraceae) from Costa Rica. J. Essent. Oil Res. 2010, 22, 259-262.

81. Su, Y.C.; Ho, C.L. Composition and in vitro cytotoxic activities of the leaf essential oil of Beilschmiedia erythrophloia from Taiwan. Nat. Prod. Commun. 2013, 8, 143-144.

82. Miller, R.E.; Tuck, K.L. Reports on the distribution of aromatic cyanogenic glycosides in Australian tropical rainforest tree species of the Lauraceae and Sapindaceae. Phytochemistry 2013, 92, 146-152.

83. Wong, R.S.Y. Apoptosis in cancer: From pathogenesis to treatment. J. Exp. Clin. Canc. Res. 2011, doi:10.1186/1756-9966-30-87.

84. Davids, M.S.; Letai, A. Targeting the B-cell lymphoma/leukemia 2 family in cancer. J. Clin. Oncol. 2012, 30, 3127-3135.

85. Lessene, G.; Czabotar, P.E.; Colman, P.M. BCL-2 family antagonists for cancer therapy. Nat. Rev. Drug. Discov. 2008, 7, 989-1000.

86. Jeng, P.S.; Cheng, E.H. Cancer therapeutics: Pulling the plug on BCL-X . Nat. Chem. Biol. 2013, 9, 351-352.

87. Placzek, W.J.; Wei, J.; Kitada, S.; Zhai, D.; Reed, J.C.; Pellecchia, M. A survey of the anti-apoptotic Bcl-2 subfamily expression in cancer types provides a platform to predict the efficacy of Bcl-2 antagonists in cancer therapy. Cell. Death Dis. 2010, 1, e40.

88. Kuete, V.; Tankeo, S.B.; Saeed, M.E.M.; Wiench, B.; Tane, P.; Efferth, T. Cytotoxicity and modes of action of five Cameroonian medicinal plants against multi-factorial drug resistance of tumor cells. J. Ethnopharmacol. 2014, 153, 207-219.

89. WHO. World Malaria Report 2014; World Health Organization: Geneva, Switzerland, 2013.

90. Clark, C.; Key, S.W. WHO releases revised facts on Malaria. Malar. Wkly. 1996, 15, 7-9.

91. Gessler, M.C.; Nkunya, M.H.H.; Mwasumbi, L.B.; Henrich, M.; Tanner, M. Screening Tanzanian medicinal plants for antimalarial activity. Acta Trop. 1994, 56, 65-77.

92. Ziegler, H.L.; Stærk, D.; Christensen, J.; Hviid, L.; Hägerstrand, H.; Jaroszewski, J.W. In vitro Plasmodium falciparum drug sensitivity assay: Inhibition of parasite growth by incorporation of stomatocytogenic amphiphiles into the erythrocyte membrane. Antimicrob. Agents Chemother. 2002, 46, 1441-1446.

93. Ray, A.; Cohn, L. Th2 cells and GATA-3 in asthma: New insights into the regulation of airway inflammation. J. Clin. Invest. 1999, 104, 985-993.

94. Hamid, Q.; Tulic, M.K.; Liu, M.C.; Moqbel, R. Inflammatory cells in asthma: Mechanisms and implications for therapy. J. Allergy Clin. Immunol. 2003, 111, S12-S17. 
95. Kuntzsch, D.; Bergann, T.; Dames, P.; Fromm, A.; Fromm, M.; Davis, R.A.; Melzig, M.F.; Schulzke, J.D. The plant-derived glucocorticoid receptor agonist endiandrin a acts as co-stimulator of colonic epithelial sodium channels (ENaC) via SGK-1 and MAPKs. PLoS ONE 2012, 7, e49426.

96. Pujols, L.; Mullol, J.; Torrego, A.; Picado, C. Glucocorticoid receptors in human airways. Allergy 2004, 59, 1042-1052.

97. Bamberger, C.M.; Schulte, H.M.; Chrousos, G.P. Molecular determinants of glucocorticoid receptor function and tissue sensitivity to glucocorticoids. Endocr. Rev. 1996, 17, 245-261.

98. Tanaka, H.; Yoshikawa, N.; Shimizu, N.; Morimoto, C. Selective modulation of glucocorticoid receptor function toward development of novel anti-inflammation: Lessons from a phenyl-pyrazolo-steroid cortivazol. Mod. Rheumatol. 2004, 14, 347-355.

99. Park, J.; Lee, J.; Jung, E.; Park, Y.; Kim, K.; Park, B.; Jung, K.; Park, E.; Kim, J.; Park, D. In vitro antibacterial and anti-inflammatory effects of honokiol and magnolol against Propioni bacterium sp. Eur. J. Pharm. 2004, 496, 189-195.

100. Fankam, A.G.; Kuiate, J.R.; Kuete, V. Antibacterial activities of Beilschmiedia obscura and six other Cameroonian medicinal plants against multi-drug resistant Gram-negative phenotypes. BMC Complem. Altern. Med. 2014, doi:10.1186/1472-6882-14-241.

101. Paulo, M.D.Q.; Barbosa-Filho, J.M.; Lima, E.O.; Maia, R.F.; Barbosa, R.D.C.; Kaplan, M.A. Antimicrobial activity of benzylisoquinoline alkaloids from Annona salzmanii D.C. J. Ethnopharmacol. 1992, 36, 39-41.

102. Setzer, W.N.; Stokes, S.L.; Penton, A.F.; Takaku, S.; Haber, W.A.; Hansell, E.; Caffrey, C.R.; McKerrow, J.H. Cruzain inhibitory activity of leaf essential oils of neotropical Lauraceae and essential oil components. Nat. Prod. Commun. 2007, 2, 1203-1210.

103. McGrath, M.E.; EaKin, A.E.; Engel, J.C.; McKerrow, J.H.; Craik, C.S.; Fletterick, R.J. The crystal structure of cruzain: A therapeutic target for Chagas' disease. J. Mol. Biol. 1995, 247, 251-259.

104. Steverding, D.; Tyler, K.M. Novel antitrypanosomal agents. Expert Opin. Investig. Drugs 2005, 14, 939-955.

(C) 2015 by the authors; licensee MDPI, Basel, Switzerland. This article is an open access article distributed under the terms and conditions of the Creative Commons Attribution license (http://creativecommons.org/licenses/by/4.0/). 